\title{
Outdoor Recreation and Nature Tourism: A European Perspective
}

\author{
Simon Bell \\ OPENspace Research Centre, Edinburgh College of Art, \\ Lauriston Place, Edinburgh EH3 9DF, U.K. \\ email: s.bell@eca.ac.uk \\ http://www. openspace.eca.ac.uk/ \\ Liisa Tyrväinen \\ Finnish Forest Research Institute, Rovaniemi, Finland \\ email: liisa.tyrvainen@metla.fi \\ http://www.metla.fi/pp/3166/

\section{Tuija Sievänen} \\ Finnish Forest Research Institute, Helsinki, Finland \\ email: tuija.sievanen@metla.fi \\ http://www.metla.fi/pp/TSie/

\section{Ulrike Pröbstl} \\ Institute for Landscape Development, Recreation and Conservation Planning, \\ University of Natural Resources and Applied Life Sciences (BOKU)

$$
\text { Vienna, Austria }
$$ \\ email: ulrike.proebstl@boku.ac.at \\ http://www.rali.boku.ac.at/6649.html

\section{Murray Simpson} \\ School of Geography and Environment, \\ University of Oxford, U.K. \\ email: murray.simpson@geography.oxford.ac.uk

\section{Living Reviews in Landscape Research ISSN 1863-7329} \\ Accepted on 18 April 2007 \\ Published on 25 June 2007
}

\begin{abstract}
Recreation and nature tourism are increasingly important activities with many implications both economic and environmental. As society changes so the demands and trends for recreation and nature tourism change and develop. This poses many challenges for planners and managers of recreational areas and providers of services. This review article focuses on the situation in Europe but does not ignore some major trends and issues arising elsewhere, while much of the research can be traced back to ideas and methods developed elsewhere, such as the U.S.A. To set the scene the main social and environmental trends are presented that show how the changing nature of society feeds through in expectations and demands for recreation and nature tourism. Demographic changes, consumer behaviour and the increasingly mobile and connected lifestyles of European citizens have produced trends for outdoor
\end{abstract}

This review is licensed under a Creative Commons 
recreation preferences and for broadening travel horizons. Knowing about these trends enables planners and entrepreneurs to change their recreation or tourism offer to meet these demands. However, these demands have to be seen in the context of changing pressures and sensitivities of the environments, frequently natural, in which recreation and nature tourism activities are located. Climate change is a prime example of these pressures. Many countries have developed sophisticated survey and other monitoring tools and instruments to identify demand, to monitor levels and types of activity, changing preferences and pressures on the environment. While recreation is often led by demand from people who wish to participate in certain activities there are also increasingly well recognised benefits to health and well-being from closer contact with nature. Policy makers in the health sphere are taking a keen interest in this and in the means for encouraging sedentary populations to engage with physical activity in natural environments. The evidence base for this is improving and is reviewed in this paper. Management of environments and visitors produces many conflicts which must be resolved. Recent surveys of forest recreation have enabled a European-wide pattern to be identified which will help planners and managers identify issues to be considered. The paper draws on work being undertaken as part of two EU funded Cost Actions: "Cost E33: Forest Recreation and Nature Tourism" and "Cost E39: Forests, Trees and Human Health and Well-being". These allow experts from around Europe to network and to pool research and practice.

Keywords: Recreation trends, visitor monitoring, health and well-being, sustainable tourism, ecotourism, recreation conflicts, forest recreation 


\section{Imprint / Terms of Use}

Living Reviews in Landscape Research is a peer reviewed open access journal published by the Leibniz Centre for Agricultural Landscape Research (ZALF), Eberswalder Straße 84, 15374 Müncheberg, Germany. ISSN 1863-7329.

This review is licensed under a Creative Commons Attribution-Non-Commercial-NoDerivs 2.0 Germany License: http://creativecommons.org/licenses/by-nc-nd/2.0/de/

Because a Living Reviews article can evolve over time, we recommend to cite the article as follows:

Simon Bell, Liisa Tyrväinen, Tuija Sievänen, Ulrike Pröbstl and Murray Simpson, "Outdoor Recreation and Nature Tourism: A European Perspective",

Living Rev. Landscape Res., 1, (2007), 2. [Online Article]: cited [<date>], http://www.livingreviews.org/lrlr-2007-2

The date given as $<$ date $>$ then uniquely identifies the version of the article you are referring to.

\section{Article Revisions}

Living Reviews supports two different ways to keep its articles up-to-date:

Fast-track revision A fast-track revision provides the author with the opportunity to add short notices of current research results, trends and developments, or important publications to the article. A fast-track revision is refereed by the responsible subject editor. If an article has undergone a fast-track revision, a summary of changes will be listed here.

Major update A major update will include substantial changes and additions and is subject to full external refereeing. It is published with a new publication number.

For detailed documentation of an article's evolution, please refer always to the history document of the article's online version at http://www.livingreviews.org/lrlr-2007-2. 


\section{Contents}

1 Introduction $\quad \mathbf{5}$

1.1 Scope of the paper . . . . . . . . . . . . . . . . . . . . . . 7

1.2 Structure of the paper . . . . . . . . . . . . . . . . . . 7

2 Drivers and trends in the demand for outdoor recreation and nature tourism in Europe and the likely implications for policy and planning $\quad 8$

2.1 Social and demographic drivers and trends . . . . . . . . . . . . . . . . . 8

2.2 Environmental drivers and trends . . . . . . . . . . . . . . . . . . . 10

2.3 Monitoring changes in recreation behaviour and assessing changes in demand . . . 13

2.4 On-site inventories: monitoring visitor flows . . . . . . . . . . . . . . . . . . . 15

2.5 Trends in recreation participation . . . . . . . . . . . . . . . 16

2.6 Trends in the development of nature tourism . . . . . . . . . . . . . . . 17

2.7 Potential benefits of nature tourism to communities . . . . . . . . . . . . . . 18

3 The increasing evidence base for health benefits of outdoor recreation and access to nature

4 Conflicts arising from outdoor recreation and nature tourism and sustainable management of resources and environments

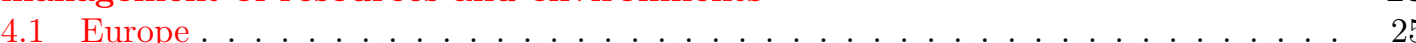

4.2 North America . . . . . . . . . . . . . . . . . . . . . . . . . . . . . . . . . . . . . . .

4.3 Principles of sustainable nature tourism . . . . . . . . . . . . . . . . . . . . . . . . . . . . . . . . . . .

4.4 Management of nature tourism . . . . . . . . . . . . . . . . . . . 34

5 Conclusions and research needs for the future $\quad 35$

5.1 The drivers of recreation . . . . . . . . . . . . . . . . . . . . . . . . . . . . . . . . . . . . . .

5.2 Health and well-being . . . . . . . . . . . . . . . . 36

5.3 Conflicts between recreation and nature tourism on sustainable use of resources and

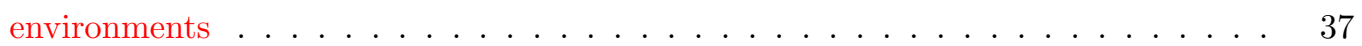

$\begin{array}{lr}\text { References } & 38\end{array}$

\section{List of Tables}

1 Participation rates in some recreation activities in six European countries, Canada and the United States in the 1990s and 2000s. . . . . . . . . . . . . . . . . 14

2 Number of visits in Finland's national parks over the years 1996-2005. . . . . . . . 15

3 Measured changes in 1982-2002 and forecasting rate of change in outdoor recreation participation 2010-2050 in the United States. . . . . . . . . . . . . . . . 16

4 Expected changes in popularity of outdoor activities in future. . . . . . . . . . . 17 


\section{Introduction}

The places associated with outdoor recreation have always included forests, the coast, lakes and rivers, mountains and other spectacular scenery that is nowadays frequently designated as national park or similarly protected. Recreation activities range from the very passive, such as sitting relaxing or enjoying a view to the very active, such as skiing, mountain biking or horse riding. They include the solitary, such as a person going for a walk by themselves or the gregarious, such as a large family picnic or a group of friends going on a hike. Outdoor recreation has a history going back many centuries, from when it was mainly the preserve of social elites who engaged in hunting, for example, through the development of the urban middle classes who visited the seaside and mountainous areas using the developing railway network to the modern car-borne mass recreation to many different destinations of today (Bell, 1997).

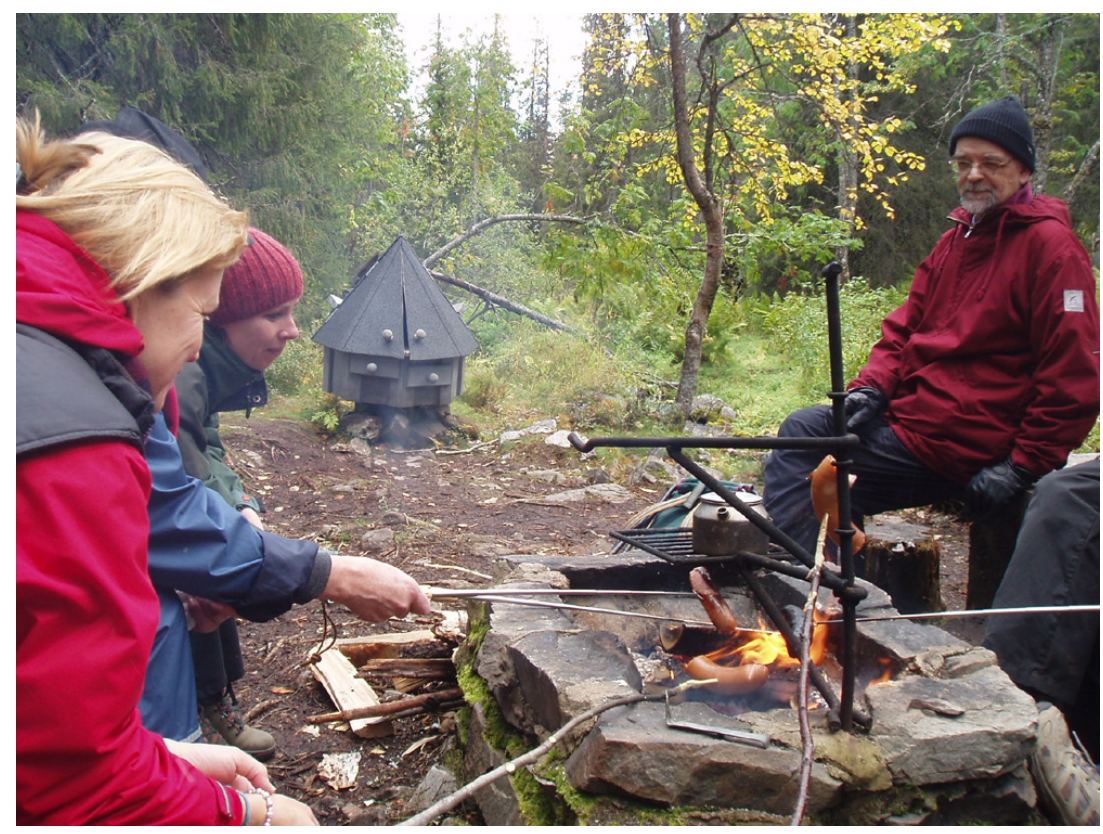

Figure 1: A typical scene in Finland, where people are cooking outdoors in the forest.

In the U.S.A., the national park movement of the 19th century saw many areas of dramatic mountain and other scenery protected as National Parks or National Monuments and these became heavily visited during the early part of the 20th century. Early infrastructure was developed by the Civilian Conservation Corps of the New Deal under the 1930s depression era legislation in the U.S.A. Post Second World War demand for recreation reached new peaks prompting the creation of a programme known as "Mission 66" which saw the development of the kind of recreation infrastructure now common around the world - car parking, trails, visitor centres, interpretative facilities and so on (Carr, 2006). In many countries outdoor recreation is focused on these places as well as more local parks or areas that are accessible on a more everyday basis. The development of recreation in other developed countries partly followed this route but with national and cultural differences. In Scandinavia, the tradition of access made possible by "everyman's right" has led to much more of the countryside being available for access than in the U.S.A., which has strong private property rights (Aasetre and Vistad, 2006). In the U.K., new legislation has opened more private land to access for recreation (Dales, 2004). These represent typical differences in accessibility to land for recreational purposes. 


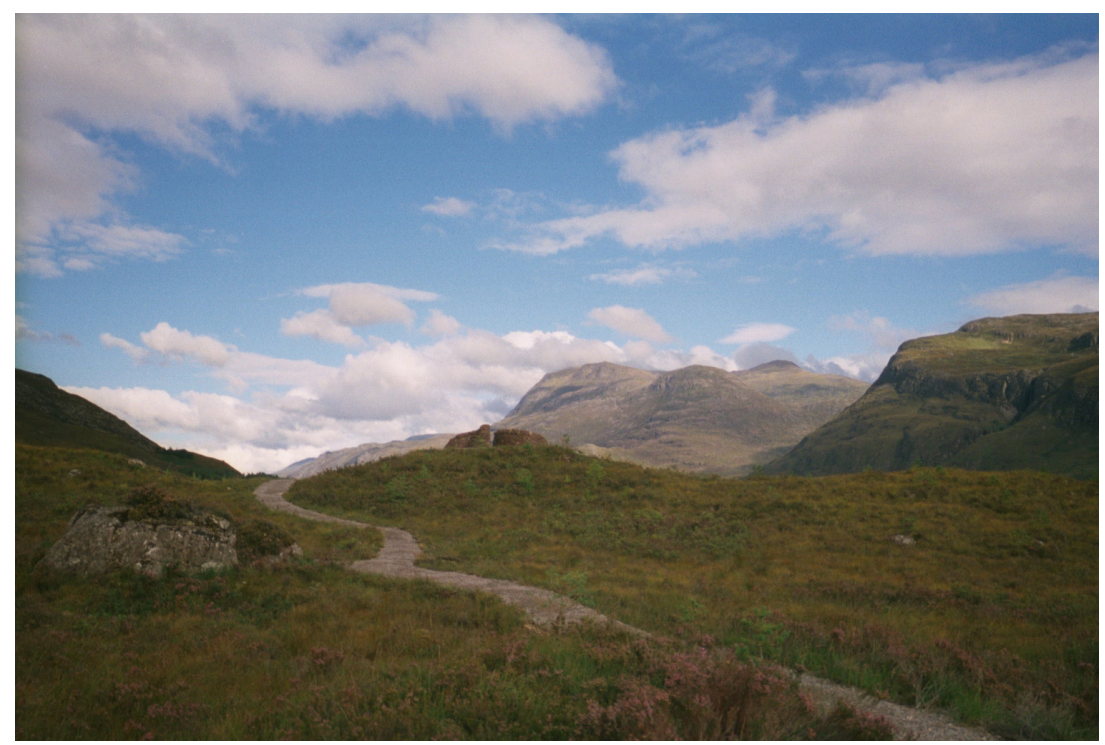

Figure 2: A path in Scotland where access to the land is much more open now than it used to be thanks to new legislation.

Terminology related to outdoor recreation and tourism is somewhat unclear. In this paper the distinction between outdoor recreation and nature tourism is as follows:

Outdoor recreation refers to activities that people undertake out of doors in places where they can access nature or green areas, mainly as part of their daily or weekend routines. Nature tourism is a term that covers activities that people enjoy while on holiday and which focus on engagement with nature and usually includes an overnight stay (Silvennoinen and Tyrväinen, 2001). Typically this means travelling to and staying overnight in locations close to or in national parks, forests, lakes, the sea or the countryside and participating in activities using these settings and compatible with their natural qualities. Another related term that is found in the literature or in common use is Ecotourism which, while connected with nature tourism (TIES, 1991), focuses rather more on travel to rural and peripheral areas of developed countries and, increasingly, to developing countries where experiencing local cultures and undertaking wilderness adventures goes hand-in-hand with benefits to the tourist such as personal growth, benefits to the area visited through volunteering, and through education by learning new ways to live on the planet. It involves travel to places where the flora, fauna, and cultural heritage are the main attractions. Responsible ecotourism aims to minimize the negative effects of traditional tourism on the natural environment. This was emphasized by the UN in 2002 with the "International Year of Ecotourism" (UNEP). Practically speaking, there are rather blurred divisions between the terms used in nature or ecotourism. This large and developing subject less easy to circumscribe than outdoor recreation. Moreover, European citizens travel outside Europe and the trends and drivers that affect their motivation apply to the whole range of recreation and tourism, of which the subjects of this paper are subsets.

As the population of the world becomes more urbanised and as concern, in particular in Europe, about health impacts of modern living, such as lack of exercise, obesity (and associated problems such as diabetes) and mental health problems (such as stress) increase, access to nature and the potential benefits of outdoor recreation has started to climb higher on the policy agenda. This does not only concern the traditional policy areas such as forestry, countryside or park management but, increasingly, the health policy areas. A European Union scientific and technical co-operation

Living Reviews in Landscape Research

http://www.livingreviews.org/lrlr-2007-2 
project "Cost Action E39: Trees, Forests and Human Health and Well-being", (2004 to 2008) has produced a series of country reports that describe the current state of policy and practice and the increasing evidence base for the role of green areas in health and well-being. (Jepson, 2005; Korpela and Sarjala, 2005; Sandur et al., 2005).

\subsection{Scope of the paper}

This review paper examines a number of trends related to recreation and nature tourism, mainly in Europe but also some important world-wide aspects, introduced above and considers some of the conflicts and the research needs raised by these trends. The subject of outdoor recreation and nature tourism is receiving a lot of attention at present in Europe and elsewhere. Another Cost Action "E33: Forest Recreation and Nature Tourism" (2004 to 2008) (Cost Action E33, 2004b) brings together 80 researchers and practitioners from 24 countries, all involved in various aspects of the field. Among the activities are a Europe-wide survey of different aspects of recreation policy, planning, management and design and a series of topic papers aimed at producing common frameworks for various aspects including visitor monitoring.

Outside Europe the most extensive research effort in outdoor recreation is probably being undertaken by the U.S.A., where concern over health and obesity caused by poor diet and lack of exercise is greater than anywhere else (Cordell, 2005). The traditional providers of recreation have been the Forest Service within the Department of Agriculture and the National Park Service supplemented by individual state park and forestry departments. These government organisations together with universities have undertaken the bulk of research while a lot of work on the ground also comes from or is funded by charitable or not-for-profit organisations.

\subsection{Structure of the paper}

This review paper provides an wide-ranging overview of the situation, mainly in Europe but also reflects current issues elsewhere, looking at a number of key themes of outdoor recreation and nature tourism that have emerged from the research community and described above.

- Drivers and trends in the demand for outdoor recreation and nature tourism and the likely implications for policy and planning; these arise from society and socio-economic developments and set the scene for the rest of the paper.

- The evidence base for health benefits of outdoor recreation and access to nature; this is a major and increasing concern for policy makers

- Conflicts arising from outdoor recreation and nature tourism and associated sustainable management of resources and environments to overcome these conflicts;

- The research needed in the near future related to each of the above themes to help policy makers, planners and managers to cope with the changing demands. 


\section{Drivers and trends in the demand for outdoor recreation and nature tourism in Europe and the likely implications for policy and planning}

Recently a number of attempts have been made to try to anticipate the trends in outdoor recreation demand likely to result from changes already underway in society. One example has been carried out in England by the Henley Centre/Headlight Vision who produced a report for the Countryside Agency which attempted to evaluate trends likely to affect outdoor recreation over the next 15 to 20 years. This report identified a large number of drivers that may affect recreation. The initial list can be grouped into a number of major themes that are likely to affect different countries and regions in different ways and to different degrees (Henley Centre, 2005). These are presented below. Some are also supported by other evidence while others emerged from stakeholder workshops and are yet to be realised. Some of these are mainly social and demographic issues while others are environmental.

\subsection{Social and demographic drivers and trends}

Demographic changes. These changes include the ageing society, where people are living longer, a trend for people to have children later, lower birth rates leading to families with fewer children, a wider range of household types, increases in ethnic diversity as a result of migration, a flow of young people to cities from the countryside, rural depopulation, reducing populations in some countries and increasing populations in others. These changes result in different patterns in the use of leisure and recreation time, for example older retired people may have many years of time for participating in recreation although as they grow older their physical abilities reduce. Another example is the decrease in traditional households, so that family outings to recreation sites are less the norm. As people have children at later ages they are able to spend more time travelling (a big impact on nature tourism demand, see below) or take more holidays.

It is difficult to underestimate the impact of this driver over time. Many statistics demonstrate the major effect of demographic changes (Eurostat, 2006), such as population reduction in rural areas in many parts of Europe. In the U.S.A., however, population growth through immigration is a significant factor (Cordell, 2005).

The affluent society. As developed countries become more prosperous and people have higher average incomes they are able to spend more of their income on leisure and recreation activities. This is also linked to the convenience culture, to the rise of the empowered consumer who wants more choice and to changing work patterns enabling people to use leisure time more flexibly. As economies mature and people already possess most of the tangible consumer products that they want they start to desire intangible products such as experiences, often gained through leisure and recreation, and especially through travel to far off places and in the pursuit of extreme adrenaline sports and experiences.

The evidence of this can be seen in some of the statistics related to nature tourism in developing countries. In 2005, there were more than 800 million international tourist arrivals globally, an increase of $5.5 \%$ on 2004 (World Tourism Organization, 2006). It is estimated that the market for nature tourism is increasing at six times the rate of tourism overall (World Tourism Organization, 2006). Some of the factors that have contributed to this growth trend in nature tourism are that people are looking for new experiences, adding diversity to their experiences, combining business travel with holidays and looking to "get back to nature" (Maetzold, 2002).

In Europe, pressure on leisure time is leading people to go on more, but shorter, trips (ETC, 2006). In addition, increased incomes and the growth of single-person households among the youth market (16-35 age group) which accounts for over $20 \%$ of global tourism, are expected to result in

Living Reviews in Landscape Research

http://www. livingreviews.org/lrlr-2007-2 


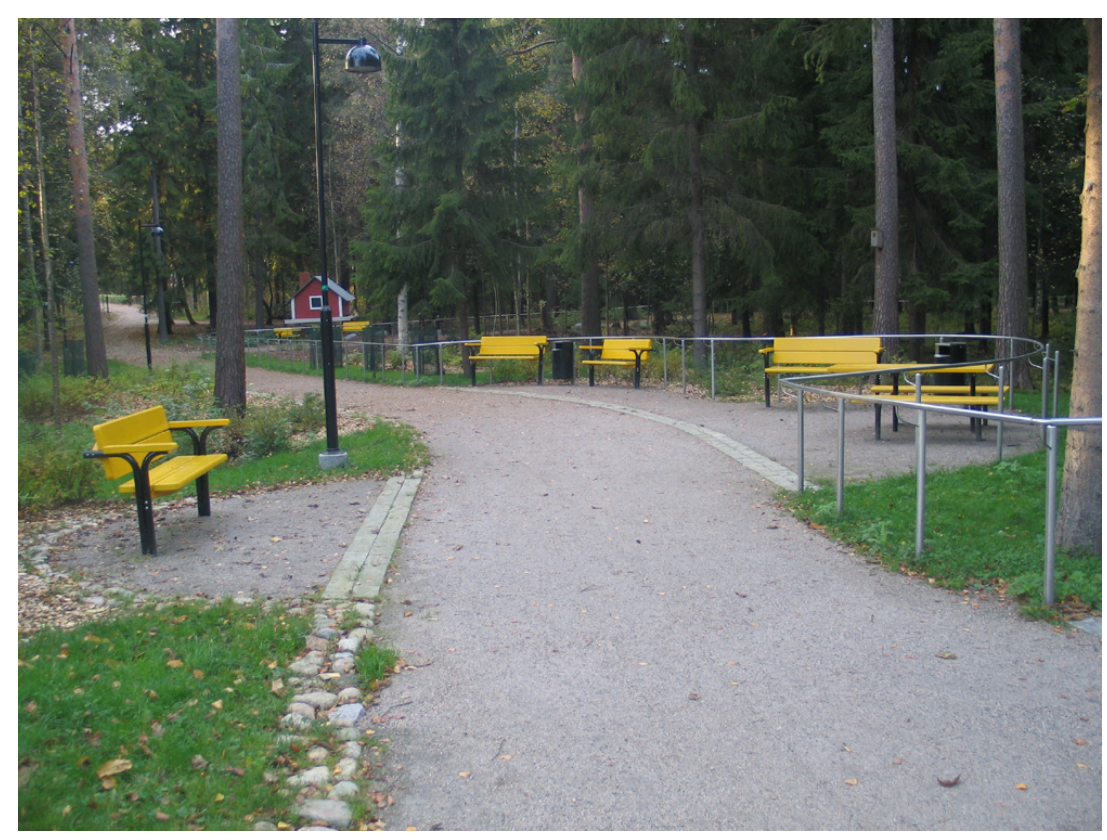

Figure 3: A trail in a park in Helsinki which has been specially laid out with older people in mind.

more active holidays, particularly adventure nature tourism (ETC, 2006).

The information society. This, with the all-pervasive influence of the internet, and of the increasingly common use of mobile phones means that people are able to obtain information and to communicate with each other very quickly and at any time of day or night (Selwyn, 2005). As a result people make plans about their leisure and recreation time very quickly, at the last minute and they also change them easily. They also make decisions on the basis of information available from recreation and tourism providers on the internet, buy travel tickets, hotels and equipment over the internet and write feedback about their experience on it.

Health and well-being. Society is increasingly concerned about the physical and mental health of its citizens, with many conditions such as obesity and stress seen as reaching epidemic proportions. Part of the concept of well-being is also associated with social inclusion, where people from disadvantaged communities are able to take part fully in society. Disability, age, poverty and poor living environments are often associated with each other and with poor health and well-being. This has led to a desire to make the outdoors, especially more natural areas accessible and used by as many people as possible. There is also what can be termed a re-tuning to nature, where people feel a desire to become reconnected to the natural world from which they feel disconnected by modern lifestyles. The increasing evidence for this is reviewed in a later section of this paper.

There has been recent work at trying to develop indices of life satisfaction that take into account the role of human, social, built and natural capital at a country level (Vemuri and Costanza, 2006). This suggests that social inclusion, as part of social capital, and natural areas as part of natural capital, are both part of the equation of life satisfaction.

Environmental and community awareness. According to the Henley Centre/Headlight Vision report people have a generally greater awareness of the environment and its problems, such as global warming, pollution and deforestation. Membership of environmental organisations is increasing and governments are taking environmental issues seriously at a national and international level. Single issue politics concerning different environmental aspects are also on the rise. Many people with such interests also want to engage in nature or ecotourism but they also wish to take 
part in activities that may have a benefit for their local environment or for that of another country. There is also a rise in communal yearning, where people want to feel part of a community and to contribute to it during their leisure time by participating in community activities. This increasing awareness of the environment and community can also help the managers of protected areas implement measures that may restrict recreational access, because people understand the need for this action.

\subsection{Environmental drivers and trends}

Landscape change. This factor is associated with the environment within which people live, work and spend their leisure and recreation time. As a result of increasing urbanisation, rural depopulation, pressures on the environment, climate change and changes in the economics of food and timber production, brought about by policy changes and global trade, the landscape is changing in different ways in different countries. In western Europe, for example, urban growth is generated by economic development, transport infrastructure and by demographic changes. This may be controlled to greater or lesser degrees by planning policies and instruments. There is also a trend for the gentrification of the countryside as people move away from the towns and cities to rural landscapes where the quality of life and community is seen to be better (Spencer, 1997).

In rural and peripheral regions landscapes are becoming abandoned as farming is uneconomic and people migrate to the towns. This can have positive effects on the environment, as pollution reduces and natural habitats increase, leading to attractive places for recreation. However, this can also reduce the quality of the landscape, the infrastructure for recreation and tourism may be at risk and the people who remain may not be well equipped with the entrepreneurial skills needed to take advantage of the potential for recreation and nature tourism (MacDonald et al., 2000)

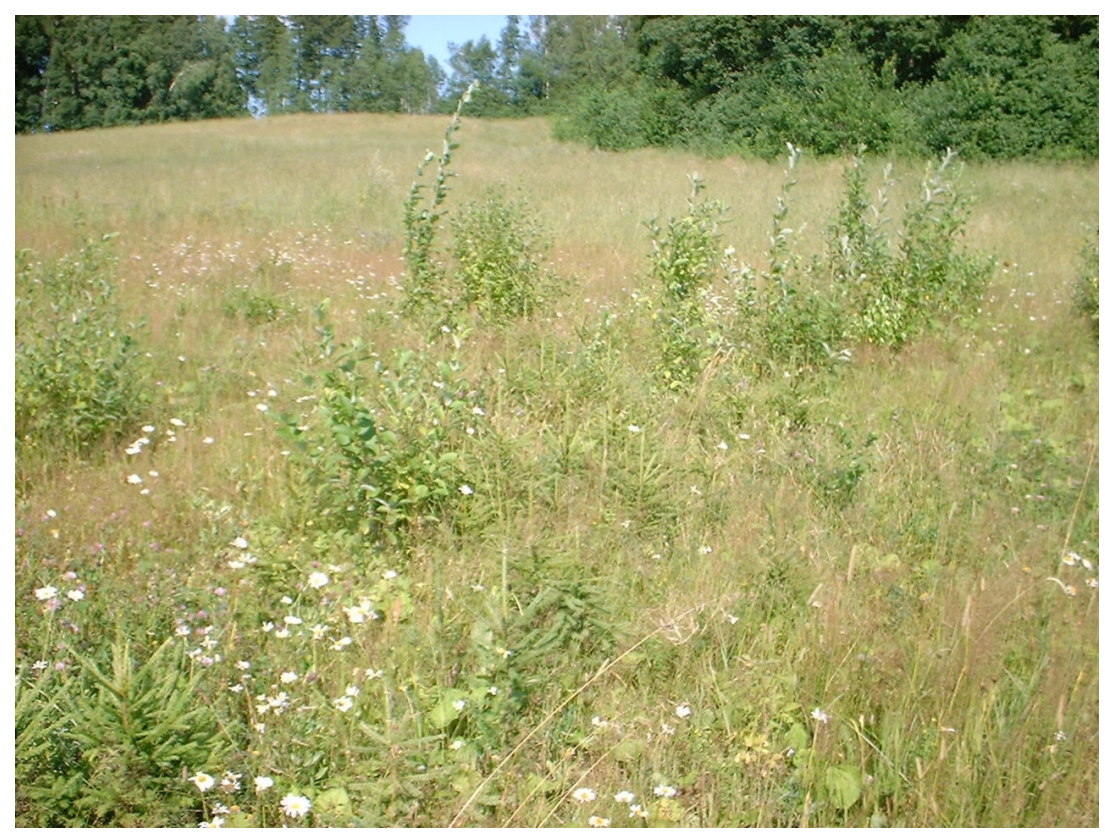

Figure 4: An abandoned field in Latvia, the result of economic and social changes in the countryside.

Climate change. With the increasing concern over climate change and the negative impact that emissions from vehicles have on the environment, visitor transport issues should be viewed as part of an integral network and alternatives created to the car or aeroplane. Climate change

Living Reviews in Landscape Research

http: //www. livingreviews . org/lrlr-2007-2 
is one of the biggest long-term threats facing not only the tourist industry but also the planet and the impacts are beginning to be felt around the world. Potentially, climate change could lead to the loss of many destinations whose appeal depends on the natural environment (ETC, 2006). For example, climate change poses a serious threat to the future health of coral reefs through the increased frequency and intensity of mass bleaching events (Grimsditch and Salm, 2006). The research conducted by (Grimsditch and Salm, 2006) not only identified the main resistance and resilience factors of coral reefs to bleaching but also management tools and strategies that can and need to be implemented to enhance reef resilience. Areas where nature tourism is dependent on high quality reef ecosystems will need to take this advice on board to minimize the impacts of climate change.

If terrestrial species are unable to move or adapt to new climatic conditions, local extinctions may occur. Vulnerable or already stressed ecosystems will be the first to be affected by climate change. Scientists have been monitoring changes in phenology for many years. Phenology is the simplest process in which to track changes in the ecology of species in response to climate change (Walther et al., 2002). Menzel and Fabian (1999) reported that in Europe, over 30 years, spring events, such as leaf unfolding, had advanced by 6 days and autumn events, such as leaf colouring, were delayed by 4.8 days. Responses by individual species to climate change may disrupt interactions with others (Walther et al., 2002). Crick et al. (1997) analysed data from the British Trust for Ornithology's nest record scheme collated between 1971 and 1996. Of the 65 species studied, 20 had significant trends towards earlier egg laying with an average of 8.8 days (Crick et al., 1997). Bird watching (avitourism) was the fastest growing nature-based tourism in the United States in 2002 (Maetzold, 2002). Any wildlife features that people want to enjoy will be affected by changes in the timings of these events. The threat of climate change has also seen an increase in the number of people visiting Alaska or Antarctica. With melting ice caps, people are obviously determined to visit these areas before they disappear.

The intensity and frequency of weather events are also increasing. In recent years, the severity of hurricanes hitting the Caribbean, Central and North America has increased These events will result in loss of land and infrastructure, negatively impacting species living in the area but may also deter tourists from visiting. Simpson et al. (2007) have conducted extensive research in Tobago on the impact of climate change on tourism in the area. The three main observed effects were found to be:

1. Changes in weather patterns; rainfall patterns causing seasonality blurring and; increase in intensity of extreme events such as storm surges and hurricanes

2. Coastal erosion of beaches and cliffs

3. Coral bleaching (Simpson et al., 2007).

To reduce the impact of climate change on nature tourism it is necessary not only to adapt but to mitigate causal effects. Simpson et al. (2007) discuss research, planning, management and action that is required to reduce, and mitigate, the potential impact that climate change will have on nature tourism in Tobago. Many of the suggestions require action before the planning or construction stage where this is still possible. A crucial interdependence exists between the climate, the environment, tourism and communities (Simpson et al., 2007). Sustainable, responsible tourism policies should be implemented and integrated into local, regional and national government strategies. Government policy plays a very important role in the development of tourism industries that are financially and ecologically sustainable (Eagles, 2001). Many natural zones cross administrative and political boundaries and this must be taken into account when developing ecotourism. Without having all nations that border an area involved, conflicts will be unavoidable.

Once the drivers and trends are understood, it is necessary for policy makers, planners and managers to have some knowledge and understanding of the likely changes in behaviour and demand 
that may affect specific areas. This is the field of visitor monitoring which, while established first in the U.S.A. has become an important tool in Europe. The next section reviews some of the systems used to assess and monitor changes in recreation behaviour and for assessing changes in visitor demand. 


\subsection{Monitoring changes in recreation behaviour and assessing changes in demand}

The need for national level information about recreation demand was already recognised forty years ago in the United States. The first National Recreation Survey (NRS) was conducted in 1960 (Cordell, 2004). The continuity of a core set of participation and demographic questions used in surveys since then has ensured that trend construction and comparisons of recreation at the level of the U.S. population over the years have been possible. Similar efforts have been taking place in other countries such as Canada, Denmark, Norway, Finland and Sweden but the contents and extent of the nationwide recreation surveys varies considerably. Without such surveys it is very difficult to calculate the level of resources needed to supply recreation, or to determine the way that trends resulting from the factors described above manifest themselves in demand. The surveys enable providers of outdoor recreation to change their strategies to meet the challenges of these changing demands.

The latest National Survey of Recreation and Environment (NSRE) 2006, recently completed in the United States, includes information collection about recreation participation and recreation trips, covering 50 different outdoor activities (see NSRE, 2003). In Scandinavia, Denmark has conducted a series of recreation surveys which offer the possibility to compare forest recreation participation over time: Danish surveys cover the overall levels of visitation to forests, and include a remarkable set of data about forest and landscape preferences (Jensen and Koch, 2004). The survey in 1993/94 reached a response rate of over $80 \%$, from samples of almost 3,000 persons (Jensen and Koch, 2004).

In Finland, only one nation-wide recreation survey (LVVI, see Sievänen, 2001) has been conducted but there are plans to repeat the study in 2008-2010. The Finnish survey data included about 10,000 respondents. The main issues measured were participation in outdoor activities, recreation trips close-to-home and trips which also included an overnight stay (Sievänen, 2001). However, while there are many differences in concepts, terms and units of measurements, some international comparisons are possible. In Table 1, participation rates of some of the most typical recreation activities in six countries have been collected to express the diversity, similarity and differences of recreation behaviour among different nations (Scrintzi et al., 1995; Jensen and Koch, 1997; Statistics Netherlands, 1997; Cordell et al., 1999; DuWors et al., 1999; Sievänen, 2001; Vaage, 2004). The idea of harmonizing approaches for recreation information monitoring, so that international comparisons can be made and so that Europe-level analysis is possible, has been discussed in the research community, particularly in the Cost Action E33. It will be seen if more comparable data is available in future. 
Table 1: Participation rates in some recreation activities in six European countries, Canada and the United States in the 1990s and 2000s.

\begin{tabular}{|c|c|c|c|c|c|c|c|}
\hline \multirow{2}{*}{$\begin{array}{l}\text { Recreation } \\
\text { activity }\end{array}$} & \multicolumn{7}{|c|}{ Participation rate in $\%$} \\
\hline & $\begin{array}{c}\text { Denmark } \\
\text { a) }\end{array}$ & $\begin{array}{c}\text { Finland } \\
\text { b) }\end{array}$ & $\begin{array}{c}\text { Holland } \\
\text { c) }\end{array}$ & $\begin{array}{c}\text { Italy } \\
\text { d) }\end{array}$ & $\begin{array}{c}\text { Norway } \\
\text { e) }\end{array}$ & $\begin{array}{c}\text { Canada } \\
\text { f) }\end{array}$ & $\begin{array}{c}\text { U.S.A. } \\
\text { g) }\end{array}$ \\
\hline Walking & 63 & 68 & 74 & 40 & 84 & & 67 \\
\hline Hiking & & 19 & & 38 & 82 & & 24 \\
\hline Bicycling & & 55 & 68 & 6 & 47 & & 29 \\
\hline $\begin{array}{l}\text { Jogging, run- } \\
\text { ning }\end{array}$ & 14 & 16 & 16 & 4 & & & 26 \\
\hline Camping & & 18 & & 2 & & 19 & 14 \\
\hline Picnicking & 10 & 28 & & 45 & & 26 & 49 \\
\hline Hunting & 1 & 8 & & 4 & 9 & 5 & 7 \\
\hline $\begin{array}{l}\text { Picking } \\
\text { berries and } \\
\text { other 'forest } \\
\text { fruits' }\end{array}$ & 2 & 57 & & & 35 & 11 & \\
\hline $\begin{array}{l}\text { Picking wild } \\
\text { mushrooms }\end{array}$ & 3 & 41 & & 21 & 13 & & \\
\hline $\begin{array}{l}\text { Cross- } \\
\text { country } \\
\text { horseback } \\
\text { riding }\end{array}$ & 1 & 2 & 6 & 3 & 4 & 2 & 5 \\
\hline $\begin{array}{l}\text { Studying and } \\
\text { enjoying na- } \\
\text { ture }\end{array}$ & 56 & 51 & & 21 & & 31 & \\
\hline $\begin{array}{l}\text { Cross- } \\
\text { country ski- } \\
\text { ing }\end{array}$ & & 40 & & 2 & 50 & 4 & 3 \\
\hline
\end{tabular}

a) A mail questionnaire regarding forest recreation on a sample of 2,826 of the Danish adult population in 1993-94, conducted by the Danish Forest \& Landscape Research Institute. (Jensen and Koch, 1997)

b) A telephone survey, sample of 12,709 among the whole population conducted by Statistics Finland and Finnish Forest Research Institute in 1998-2000 (Sievänen, 2001).

c) A diary survey by Statistics Netherlands (CBS) in 1995-96 (Statistics Netherlands, 1997).

d) A mail questionnaire on sample of 3,000 of the whole Italian population in 1995; recreation activities in forest (Scrintzi et al., 1995).

e) (Vaage, 2004)

f) The Nature Survey, sample of 86,951 Canadians by Statistics Canada in 1997 (DuWors et al., 1999).

g) NSRE telephone survey of sample of 12,000 people in 1994/95 (Cordell et al., 1997).

Empty space refers that a comparable figure was not available. 


\subsection{On-site inventories: monitoring visitor flows}

On-site recreation inventories, i.e. visitation monitoring systems, are an important part of the whole management policy of recreation and protected areas in many countries. The recreation monitoring system most often applied is a science-based system for data collection, data management and reporting, which supplies updated visitor information on a continuous basis for policy makers and managers. Monitoring systems differ between countries, but often standardization of methods and harmonization of information content has taken place within one country or at least within one public land agency.

The most common visitation information measured includes number of visits, duration of visit and distribution of visitors over the recreation area. Information gathered from visitors usually consists of socio-economic factors such as sex, age, income and municipality/region/country of residence, length and means of travel and amount of money spent. Visitor behaviour patterns describe the level and type of participation in recreation activities, the length of stay in the area and the make up of the group who made the visit. Visitor satisfaction, motives and the expectations of visit and experiences are also studied in most cases. As a result of Nordic-Baltic project on visitor monitoring a new manual (Kajala, 2006; Kajala et al., 2007) is going to be published in 2007. The coming manual offer recommenadations to choose variable, measures and sample methods for visitor monitoring.

The United States Forest Service has implemented a sophisticated on-site visitor monitoring system called the National Visitor Use Monitoring System (NVUM). With this system, one fourth of the 160 national forests in the country are sampled each year through a system of site-day sampling. Activities, duration of visit, satisfaction, trip spending profiles and sites visited are collected and GIS referenced to provide location-specific, regional, and national estimates to guide policy, management, maintenance, budgeting and customer responsiveness (English et al., 2002).

Table 2: Number of visits in Finland's national parks over the years 1996-2005. Source: Metsähallitus (2006), Finland.

\begin{tabular}{|c|r|}
\hline Year & Number of visits \\
\hline \hline 1996 & 714,000 \\
1997 & 749,000 \\
1998 & 771,000 \\
1999 & 787,000 \\
2000 & 833,000 \\
2001 & 852,000 \\
2002 & $1,012,000$ \\
2003 & $1,123,000$ \\
2004 & $1,285,000$ \\
2005 & $1,410,000$ \\
\hline
\end{tabular}

In Denmark, automatic monitoring of the car-based forest visitation at four selected forest areas was established in the mid 70's and has been going on ever since. In addition, on-site inventories have been carried out in more than 300 forest areas in 1976-77 and again in 1996-97 in more than 500 Danish forest and nature areas (Jensen and Koch, 1997). In the United Kingdom, visitor counting and surveys are also widely applied and used in planning and management processes. Finland has standardized visitor study procedures in order to obtain comparable visitor 
information from all state owned recreation and protected areas (Erkkonen and Sievänen, 2002; Rauhala et al., 2002). The national recreation management policy uses visitor surveys in order to develop customer-driven management in recreation areas. In many other European countries, even though a majority (85\%) has conducted some studies about recreational visits to specific recreational sites, systematic and standardized visitor information collection systems are still in a developmental stage (Skov-Petersen and Jensen, 2005).

An example of trends based on systematic visitor counting in national parks comes from Finland. The Metsähallitus (Forest and Park Service), which manages the majority of state owned forest lands in Finland, has monitored recreational use in national parks and state owned hiking areas for over ten years (Table 2). It shows how the basic trend is for an increased level of visitation. The pattern varies across each park and this enables the identification of places where visitor levels start to place pressure on natural resources, for example, or those locations that are particularly sensitive to recreation activities.

\subsection{Trends in recreation participation}

The science based information of existing trends in recreation behaviour is best documented in the United States, where monitoring of participation in outdoor activities has continued since early 1960's. According to Cordell et al. (1999); Cordell (2004, 2005) and the Interagency National Survey Consortium (NSRE, 2003), participation in all outdoor activities has been increasing when measured in terms of the total numbers of participating people (Table 3). This increase in total participation rates is partly due to the increasing population. However, the numbers of visits and visiting people matters when looking at the pressures of recreational use on natural resources, which tend to be finite.

Table 3: Measured changes in 1982-2002 and forecasting rate of change in outdoor recreation participation 2010-2050 in the United States. Sources: a) Cordell et al. (1997), b) NSRE (2003), c) Cordell (2004).

\begin{tabular}{|l|l|l|l|l|l|l|l|l|}
\hline \multirow{2}{*}{$\begin{array}{l}\text { Participants, } \\
\text { millions }\end{array}$} & \multicolumn{3}{|c|}{ Measured } & \multicolumn{3}{c|}{ Index of forecast c) } \\
\cline { 2 - 10 } & $\mathbf{1 9 8 2}$ a) & $\mathbf{1 9 9 4}$ b) & $\mathbf{2 0 0 2}$ c) & $\mathbf{2 0 1 0}$ & $\mathbf{2 0 2 0}$ & $\mathbf{2 0 3 0}$ & $\mathbf{2 0 4 0}$ & $\mathbf{2 0 5 0}$ \\
\hline $\begin{array}{l}\text { Cross-country } \\
\text { skiing }\end{array}$ & 5.3 & 6.5 & 8.1 & 1.15 & 1.23 & 1.49 & 1.67 & 1.91 \\
\hline Downhill skiing & 10.6 & 16.8 & 18.1 & 1.09 & 1.16 & 1.36 & 1.54 & 1.82 \\
\hline Snowmobiling & 5.3 & 7.1 & 11.7 & 1.00 & 1.05 & 1.08 & 1.13 & 1.22 \\
\hline Hunting & 24.7 & 18.6 & 23.7 & 0.97 & 0.98 & 0.98 & 0.98 & 0.99 \\
\hline Hiking & 24.7 & 47.8 & 69.7 & 1.04 & 1.11 & 1.19 & 1.24 & 1.31 \\
\hline Backpacking & 8.8 & 15.2 & 22.2 & 0.93 & 0.99 & 0.91 & 0.91 & 0.94 \\
\hline $\begin{array}{l}\text { Camping primi- } \\
\text { tive }\end{array}$ & 17.7 & 28.0 & 33.9 & 0.92 & 0.98 & 0.87 & 0.84 & 0.84 \\
\hline Walking & 93.6 & 133.7 & 175.4 & 1.07 & 1.15 & 1.22 & 1.27 & 1.33 \\
\hline Fishing & 60.1 & 57.8 & 72.2 & 1.05 & 1.12 & 1.17 & 1.21 & 1.27 \\
\hline Sailing & 10.6 & 9.6 & 11.1 & 1.06 & 1.13 & 1.24 & 1.33 & 1.48 \\
\hline Motor boating & 33.6 & 47.0 & 51.8 & 1.06 & 1.13 & 1.21 & 1.29 & 1.40 \\
\hline Horseback riding & 15.9 & 14.3 & 20.5 & 1.07 & 1.18 & 1.28 & 1.39 & 1.54 \\
\hline
\end{tabular}

Living Reviews in Landscape Research

http://www. livingreviews.org/lrlr-2007-2 
In the United States, most rapidly increasing numbers of participants are in walking, sightseeing, swimming, picnicking and boating. In general, traditional outdoor activities such hiking and camping are still growing at a moderate rate, while consumptive activities such as hunting are declining. New types of activities such as viewing fish and wildlife and motorized outdoor activities such as snowmobiling or jet skiing are activities that are increasing most in popularity (Cordell, 2005). Table 4 shows these trends.

Table 4: Expected changes in popularity of outdoor activities in future (Cordell, 2004, 2005).

\begin{tabular}{|l|l|}
\hline Fastest growing activities & Slowest growing activities \\
\hline \hline Kayaking & Motor-boating \\
Snowboarding & Primitive camping \\
Jet skiing & Sailing \\
View or photograph fish & Visit historic sites \\
Snow-mobiling & Downhill skiing \\
Ice Fishing & Snorkeling/scuba \\
Sledding & Visit beach/waterside \\
View wildlife & Anadromous fishing \\
Backpacking & Caving \\
Day hiking & Small game hunting \\
Bicycling & Migratory bird hunting \\
Horseback riding & Picnicking \\
Canoeing & Warm-water fishing \\
& Saltwater fishing \\
& Swimming \\
\hline
\end{tabular}

As in the United States, the traditional consumptive activities of hunting and picking wild berries and mushrooms seem to be in decline in popularity in Scandinavia (Lindhagen and Hörnsten, 1998; Sievänen, 2001; Sievänen et al., 2004). Instead, snowmobiling is increasing in popularity. In most European countries there is no long term monitoring or statistics of outdoor recreation, so that it is less easy to spot these trends, but it is very likely that many of the trends that are now seen in the United States, likely to develop in Europe.

This section has shown that the assessment of behaviour and demand is essential for creating a picture of emerging patterns and trends so that policies can be developed and planning take place with the best information possible. However, it is obvious that these systems are mainly available and implemented in developed countries with often mature economies and where legislation and other instruments are available to manage supply and demand. They are less likely to be available in developing countries.

\subsection{Trends in the development of nature tourism}

Nature tourism is a rapidly expanding activity throughout the world which encompasses many different activities but essentially includes those which involve participants engaging with nature. The industry segment takes place in predominantly natural settings with the added emphasis of fostering understanding and conservation of the natural environment (Newsome et al., 2002). 
Nature tourism can take many forms, ranging from the passive (enjoying a view, painting) to the active (white-water rafting, mountain biking) and from the consumptive (fishing, hunting) to the non-consumptive (walking, bird-watching). Ecotourism, a term that has been increasing in popularity in recent years, is one niche market within the larger nature tourism market (Halpenny and Otte, 1999). The International Ecotourism Society defines ecotourism as "responsible travel to natural areas that conserves the environment and improves the well-being of local people" (TIES, 1991). Nature tourism has the potential to provide many opportunities, as illustrated in Figure 5.

Stueve et al. (2002) estimated that natural areas, and their closely associated local cultures, and the various related tourist, recreational and leisure activities, contribute around half the total economic activity attributable to the travel and tourism sector. This equates to approximately US\$ 340 billion in 2005. Tourism is the principle 'export' (foreign exchange earner) for $83 \%$ of developing countries (Mastny, 2001). Nature-based tourism diffuses economic benefits to rural or peripheral regions because the main natural and heritage attractions are often away from urban or industrial areas.

\subsection{Potential benefits of nature tourism to communities}

Many private, public and community landholders are turning to nature tourism as a profitable adjunct or replacement for farming, forestry or fisheries. In the past, the main function of forests in Europe was that of wood production. Today, in many European countries that are largely forested nature tourism is increasingly seen as an important chance to diversify the means of livelihood in rural areas (Tyrväinen et al., 2002). With the decline in the importance of this as a management goal in many regions, nature tourism is often looked upon as a means for rural development (Cost Action E33, 2004a), see Figure 5. Though there is also the danger of negative impacts; severe pressures on many forest areas in danger of being degraded ecologically and physically due to high recreational use (Cost Action E33, 2004a).

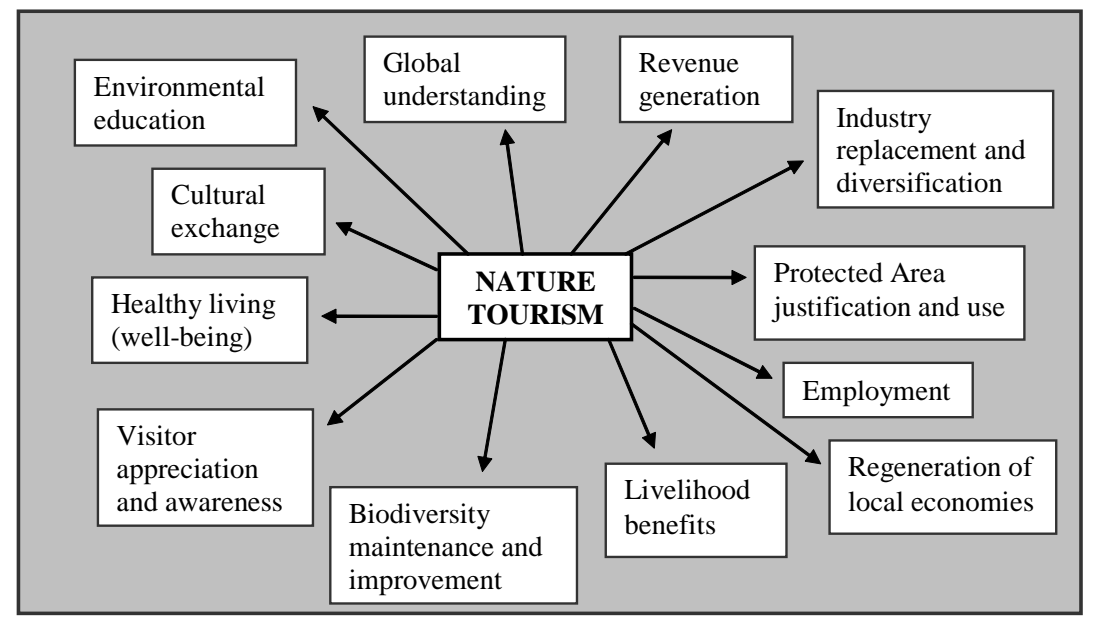

Figure 5: Potential benefits resulting from Nature Tourism.

The possibilities and interest of developing nature tourism vary between European countries. In Finland, almost $80 \%$ of the population live in urban environments and, in $2004,40 \%$ of the adult population took nature trips equating to an average of nine trips per person per year (Silvennoinen and Tyrväinen, 2001). Currently, nature tourism businesses are often relatively small scale and mostly part-time enterprises combined with agriculture and forests. In some area such

Living Reviews in Landscape Research

http://www. livingreviews.org/lrlr-2007-2 
as in Lapland, Finland nature tourism is already the most important sector contributing the regional economy (Tyrväinen, 2006). Furthermore, new forests are also being established with public recreation very much in mind, often close to large centres of urban population (Cost Action E33, 2004a).

Tourism based on natural environments is an increasing international industry with major economic, social and environmental consequences at both local and global scales (Buckley, 2003). Many of the conflicts emerging as a result of nature tourism differ between developing and more developed countries. People in developing countries who live in areas that are often most attractive to nature or eco-tourists often rely on products, services, or land from natural areas, to meet their livelihood needs (Salafsky and Wollenberg, 2000). In these situations, demand on resources can conflict with conservation or tourism requirements. Incursions into protected areas, whether for wildlife poaching or subsistence hunting, are commonplace. Moreover, tourism may create a dependency on a volatile, seasonal industry and it may conflict with other livelihood activities such as fishing or agriculture (Ashley et al., 2000). In largely forested countries in northern Europe tourism industry competes with commercial forestry and timber production. Salafsky and Wollenberg (2000) developed a conceptual framework for defining the linkage between livelihood activities and conservation. They found that if there is a direct linkage, so that livelihoods are dependent on biodiversity, or where the local community benefits economically, they are more likely to taken action to counter threats to resources (Salafsky and Wollenberg, 2000).

There are a number of common strategies required to develop successful nature tourism operations irrespective of region or country. The European Commission produced a comprehensive report that detailed and developed fifteen principles for the management of rural tourism (European Commission, 2000) that can be adapted and applied to nature tourism. The document also contains information on the components of good practice for rural tourism. Three of the areas for which guidance was provided concerned working together to a strategy, delivering a quality (rural) tourism experience and strengthening quality management and monitoring processes (European Commission, 2000). 


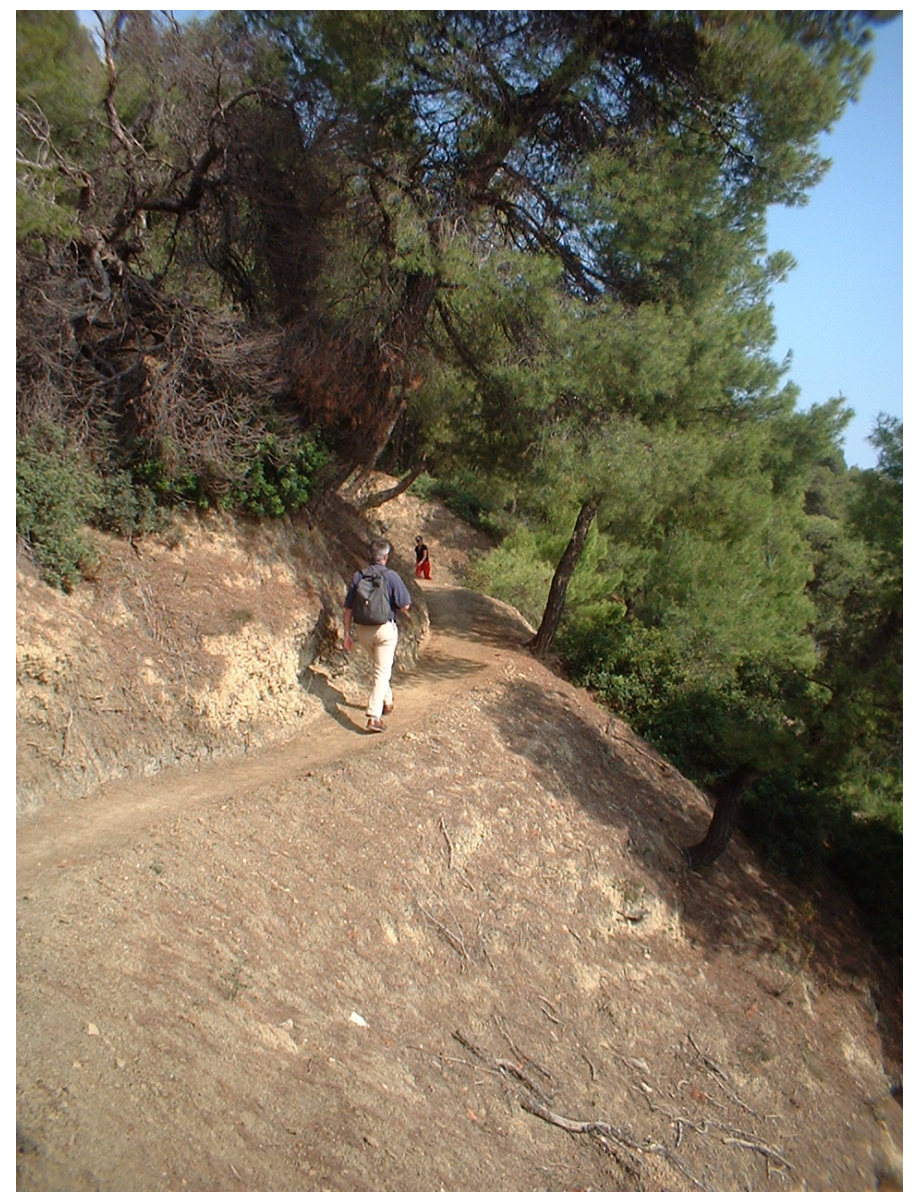

Figure 6: A hiking path in Halkidiki in Greece provides opportunities for nature tourism. 


\section{The increasing evidence base for health benefits of out- door recreation and access to nature}

As identified in the section on the drivers of future outdoor recreation, health and well-being is an increasing area of research. The body of literature in Europe supporting positive links between active and passive use of natural environments and human health is increasing but still relatively fragmented (Morris, 2003). Evidence suggests that forests and other nature areas help in people's recovery from stress and attentional fatigue. Outdoor recreation is well on the way to becoming an important element of a healthy living and a remedy against the deficiencies of a modern life separated from nature. People with special needs such as the elderly or those with physical or mental disability often gain therapeutic benefits from activities conducted in natural environments. Mental well-being is supported also through the role that play takes in helping to establish personal and community identity for children and young people.

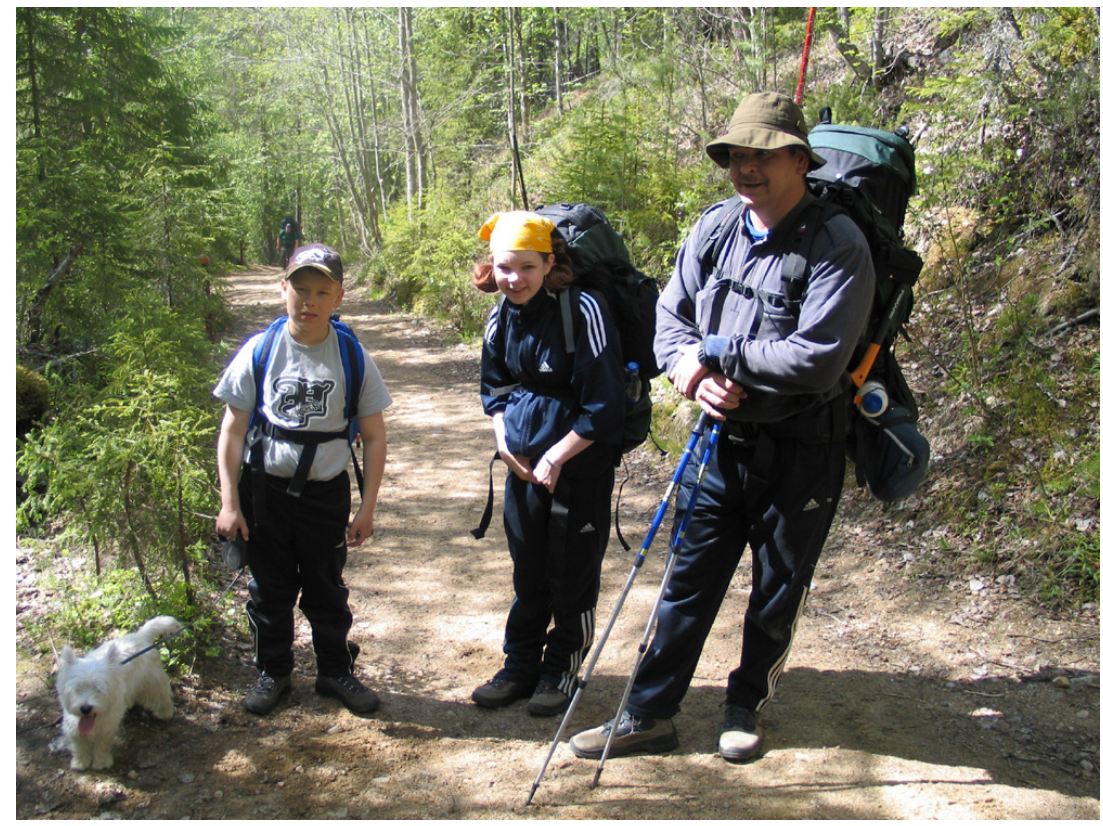

Figure 7: Encouraging young children to be active outdoors is important for their physical and social development.

By offering an attractive environment for recreational activities, forests may seduce people with a sedentary life style to become more active during their leisure time. Activities such as recreational walking and cycling already have a positive effect on health. It has been shown that more green space within the living environment leads to people visiting natural environments more often (e.g. Grahn and Stigsdotter, 2003; Tyrväinen et al., 2005). However, a higher number of visits to green areas does not automatically mean that these people are more physically active. For example, people living in a less green environment may still walk often, but do so more frequently in a built-up area as opposed to a green space.

Urban forests and parks near to where people live are especially important for elderly and young people who are restricted in their capacity to travel. The most active users of neighbourhood forests are probably children. There are also programmes that try to stimulate people to become physically active within the local natural environment, for example in the United Kingdom (Ashcroft, 2002; O'Brien, 2005). When they do go for a walk, a lack of nearby nature-based opportunities tends 
to increase the number of people using a car and subsequently leads to driving longer distances to visit an attractive natural area (de Vries, 2000). The key factor for active use is easy access to the areas, preferably within walking distance from home. In a survey study in Salo, Finland half of the respondents noted that the main reason for not using urban recreation areas was the distance to get there (Tyrväinen, 2001).

The most sought after experiences are mainly enjoying the natural scenery, peace and quiet. These qualities are sought, if possible, near home, but increasingly they can be found only in rural and peripheral urban areas. Finnish nature tourists, for example, look for quiet and peaceful surroundings as well as the possibility to move independently in a natural environment. In addition, hiking trails and constructed facilities for the outdoors were emphasized, while guided activities and excursions were seen as less important. The Finns seem to retain a relatively close association with nature and to retain the skills needed to manage independently in natural places. However, the urbanization process also taking place in Finland may increase the demand of guided activities in the future (Tyrväinen et al., 2003).

Tourists mainly evaluate the environment in terms of landscape, where attractive scenery becomes one of the most important reasons for the choice of destination (Tyrväinen et al., 2001). In Finland, almost $80 \%$ of people live in cities or population centres, but almost half of Finns (48\%) are interested in taking a nature trip within a year and $26 \%$ within the next few year. Most people $(28 \%)$ were interested in taking a trip to a national park, hiking, fishing or hunting area owned by the state. Private cottages were also a relatively popular travel destination (16\%). Tourists were willing to travel an average of $380 \mathrm{~km}$ from their home municipality to a nature area. Today, the majority of national parks are located in Lapland, some 800-1000 kilometres from the capital, Helsinki Metropolitan area. Therefore, the demand for shorter travel distance puts more pressure for developing nature tourism services in commercial forests located in South-Finland, mainly in private ownership (Tyrväinen et al., 2003).

If open to the public, recreational use of forests tends to be rather intensive in highly populated countries such as the Netherlands. Forests, however, have a relatively large "social capacity" per hectare, because of the screening effect of trees there can be many people present without the area feeling crowded. The perception of crowdedness obviously also depends on visitor expectations. However, people's recreational motives vary and different user interests often lead to conflicts (see below). For example, those who want to go for a walk in a quiet and natural environment may feel disturbed by others, who pursue hobbies such as horseback riding and mountain biking (e.g. Seeland et al. (2002). In the future, motorized use of natural areas is likely to be in increasing conflict with activities linked with experiencing peace and quietness and solitude.

Psychological well-being does not necessarily have to be derived through physical activity. An important positive health effect of viewing and experiencing nature is its stress reducing effect. Research aiming to replicate original studies in the United States (Ulrich et al., 1991) has led to similar results in Sweden (see e.g. Hartig et al., 1996). Just visually experiencing a natural setting can be shown to reduce stress. Stress relief, as measured through muscle tension, blood pressure and electrical brain activity, can be demonstrated within some minutes of exposure to a green environment (Ulrich et al., 1991). Moreover, viewing or visiting natural environments (compared to built urban environments without natural elements) after stressful or mentally fatiguing situations, produces greater physiological changes toward relaxation and faster recovery of attention-demanding cognitive performances (Parsons et al., 1998).

There are only a few epidemiological studies on the relationship between nature and health. A study in Sweden by Grahn and Stigsdotter (2003) demonstrated that the more often one visits green areas the less often one reports sickness from stress. An epidemiological study performed in the Netherlands by (Maas et al., 2006) showed that residents of neighbourhoods with abundant green space tend, on average, to enjoy better general health. This positive link was found to be most apparent among the elderly, housewives, and people from lower socioeconomic groups. Moreover,

Living Reviews in Landscape Research

http://www. livingreviews . org/lrlr-2007-2 


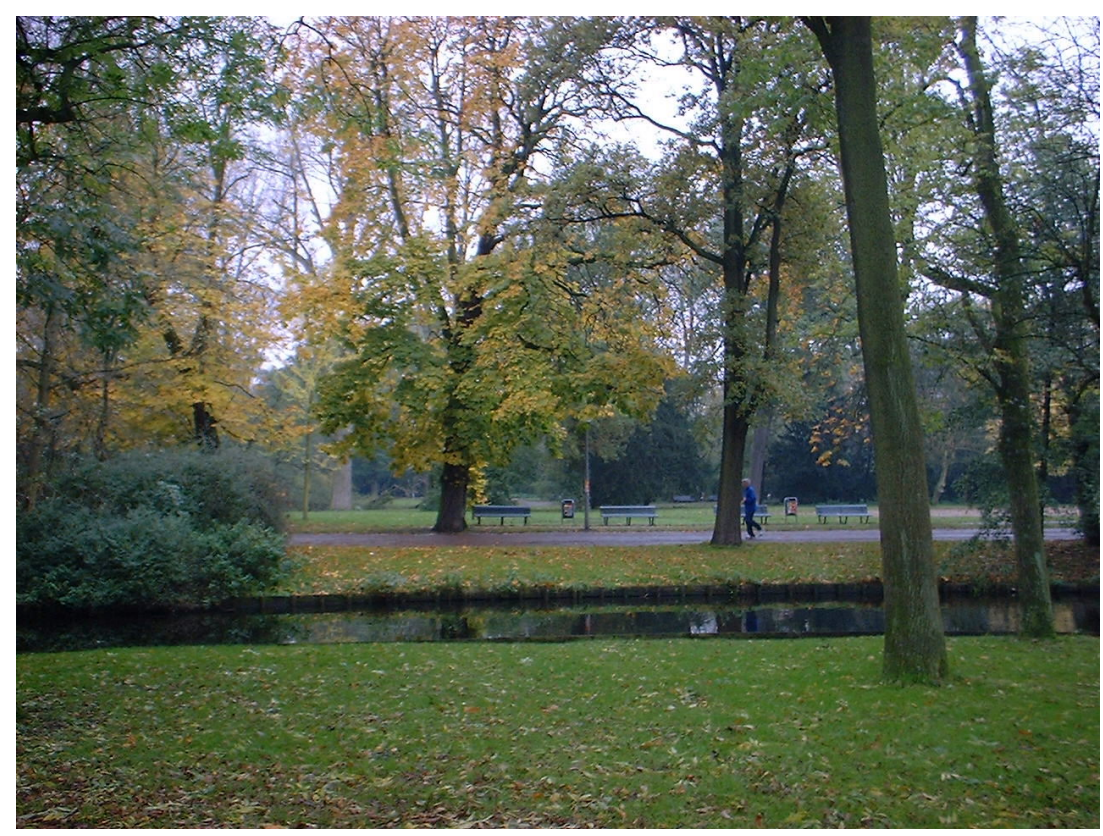

Figure 8: An urban park in the Netherlands provides valuable green space in a crowded country.

a recent study in Finland (Tyrväinen et al., 2006) conducted in two largest cities showed that perceived stress symptoms and self-reported health was influenced by the total amount of time spent in natural areas. Similar results have been found in the U.K. (Bell et al., 2005). The results suggest that exposure to nature areas increases positive emotions while negative emotions decrease only when exposure to natural areas is relatively high. Weekly contact with nature within work or study was found to increase positive emotions and decrease negative emotions.

It is unclear to what extent the mechanism behind this restorative effect is evolutionary in character and/or cognitively mediated. Studies related to restorative environments show that people use favourite places often located in natural environments to regulate their self-experience and feelings. Moreover, these places are usually aesthetically appreciated and provide an opportunity for self-expression. Restorative outcomes, i.e. relaxation, decrease in negative feelings, forgetting worries, and recovering attention focus have characterised visits to natural favourite places (e.g. Hartig et al., 1991; Korpela and Hartig, 1996).

A high aesthetic quality may not be required for a stress reducing effect, but might be helpful to attract people to the recreation area. One precondition, however, is quite generally thought to be important for restorative effects: safety. The (assumed) presence of potentially dangerous other people will diminish positive health effects. As mentioned before, common motives for visiting forests and natural environments are experiencing solitude, peace and quietness. These qualities may also be conducive to the stress-reducing effect. However, crime statistics, for example in the United Kingdom, show that physical attacks are rare in woods, and that such concerns are often based on perceptions rather than reality (Burgess, 1995). One of the key factors for security is visibility, which requires active management of the understorey, and giving the impression that the area is controlled (Tyrväinen et al., 2003; Thompson et al., 2004).

Another possible mechanism relating nature to health is that of social interaction and cohesion. While European research in this topic is still scarce, several studies conducted in Chicago suggest that green space, especially trees, may help to facilitate (positive) social interaction with neighbourhood members (see e.g. Kweon et al., 1998). This is suggested to reduce feelings of social 


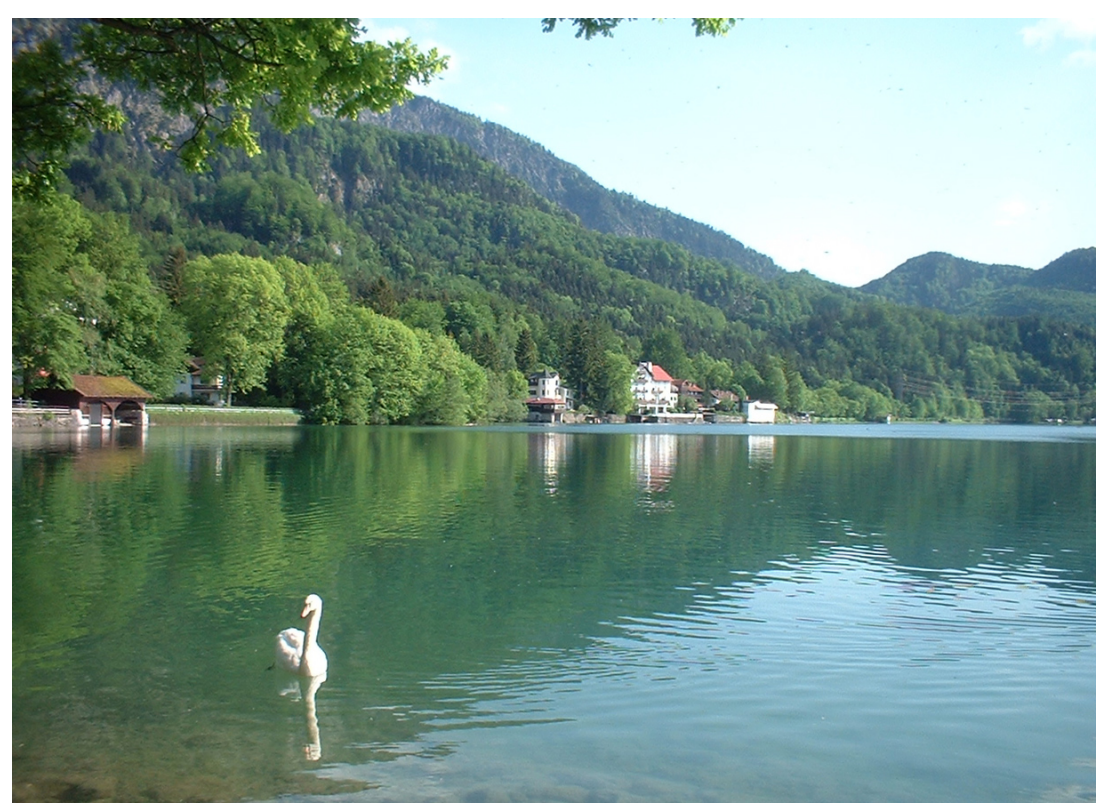

Figure 9: High quality landscapes are frequently associated with good restorative values.

isolation, which is a risk factor related to depression. Although it is still unclear what are the most relevant mechanisms behind the health effects, recent Dutch research has shown that the relationship between the amount of green space in the living environment and self-reported health is positive, even after controlling for relevant socio-demographic and socio-economic characteristics (de Vries et al., 2003).

Moreover forests contribute to a better quality of living environment in the cities, for example by improving air quality and consequently the health of urban residents. The leaves of trees can take up many pollutants, e.g. ozone, nitric acid vapour, nitrogen dioxide, ammonia, sulphur dioxide and particles (aerosols and dust). Some of these pollutants can cause serious health problems. Trees also provide valuable shading from the sun. An individual tree can provide Sun Protection Factor (SPF) of 6 to 10, which means a level of exposure to ultraviolet radiation of one sixth to one-tenth of full sun (NUFU, 1999). 


\section{Conflicts arising from outdoor recreation and nature tour- ism and sustainable management of resources and envi- ronments}

The previous section examined the general issues of nature tourism and some of the conflicts that arise, mainly between over development and damage to the resources from too many visitors. This section considers the conflicts involved in the management of natural areas, especially forests, across different parts of the world. Here there are not only conflicts between recreational or tourism visitors and the natural resource but also among and between recreational activities. This presents many challenges to managers. However, not all conflicts occur everywhere and there are distinct regional patterns that emerge from an analysis of different countries. The first part looks at the situation in Europe which is best known to the authors from work on Cost Action E33. This is followed by summaries of the situation from other regions.

\subsection{Europe}

The following review is based on the analysis of a survey which was undertaken for the Cost Action E33 programme mentioned above. It was the first attempt to produce a picture of the situation across the whole of Europe and it reflects the situation of the present time. Survey questions were designed to reflect expert knowledge, in relation to forest functions, forest management, and forest based recreation management. One survey form was sent to a representative of each country, who was asked to complete the survey in collaboration with other national experts knowledgeable in the respective fields (see Figure 10). This type of questioning prevented one single expert from responding solely on the basis of personal observations and opinions.

The results include the answers from forest practitioners and researchers working within the respective regional or national forestry administrations of each country (Pröbstl, 2005; Pröbstl et al., 2007). The survey was addressed to the national representative member of the Cost Action programme, who was invited to be responsible for the questionnaires in his or her country based mainly on personal invitations leading to a high response rate (over $80 \%$ ).

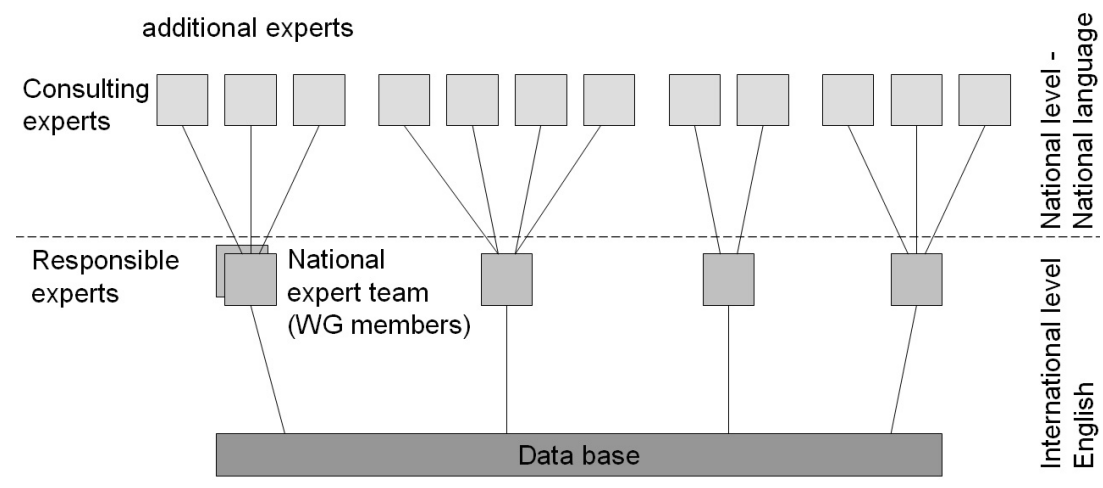

Figure 10: The concept of the expert based survey.

In the following, some results of this survey (Pröbstl et al., 2007) concerning conflicts in recreation management are presented. The first approach showed a rather diverse picture which showed some basic trends. However, a more differentiated analysis and discussion with the experts was able to identify significant regional variations (see Figure 11). 
Figure 11 summarizes the most important types of conflicts across Europe. It can be seen that in countries which are characterized only by a small amount of forest (for example the U.K.) and those with an intensive and very productive forestry (such as Finland and Norway) most of the conflicts occur between "recreation and forest use", mainly timber harvest activities where health and safety considerations as well as difficulties in using harvested areas for recreation were cited as reasons. In densely populated countries the conflicts between different user groups tended to dominate (for example Belgium, Denmark and Germany). This is because there are often many user groups competing for space. In the Mediterranean countries and France hunting is considered as the most severe problem causing conflicts with recreation.

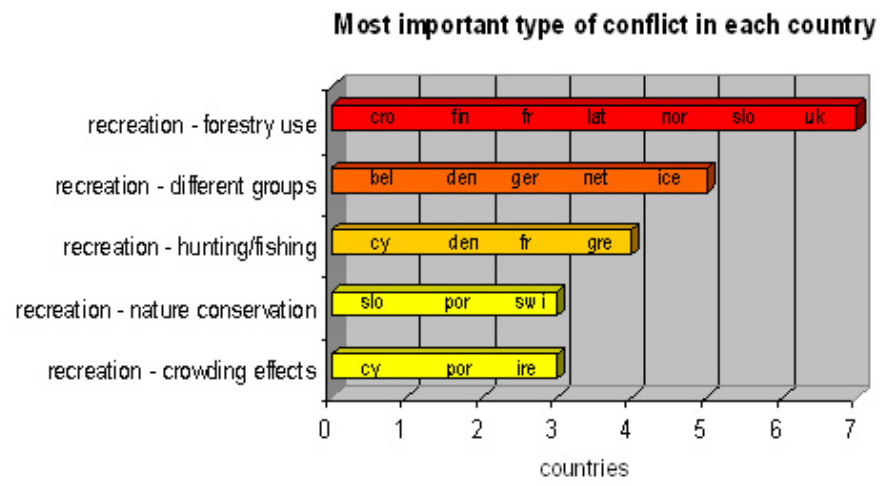

Figure 11: The most important types of conflict identified for each country participating in the survey.

However, analysis of the pattern of conflicts arising from outdoor recreation and nature tourism and the sustainable management of resources and environments revealed significant regional differences. Overall, five regional groups of countries emerged which are characterised by similar foci, conflicts and management tasks (Figure 12):

- The Atlantic region

- The Central European region

- The Mediterranean region

- The Nordic region

- The Continental region

Below, the main concerns and challenges for each region are described. The relative priority of these topics is influenced significantly by the overall amount of forest, the population density, the legal situation, and, especially, access.

The Atlantic Region is characterised by a very low proportion of forest cover per country, usually in the region of $5-11 \%$. In Iceland, Ireland, Denmark, the U.K. and the Benelux countries, the provision of recreation opportunities is of utmost importance as forests represent one of the main types of accessible land use for recreational purposes. The high population density and relatively low proportion of forest $(<11 \%)$ leads to an emphasis on recreation as a major policy objective for forest management and a subject of a focus both in research and practice. The main challenges for management are the aesthetic enhancement of plantation forests for the purpose of recreation and the development of urban forestry (among others, Heytze and Herbert, 1990; McCormack and O'Leary, 1995; Bell, 1997). Compared to other regions, the main conflicts are crowding and the

Living Reviews in Landscape Research

http://www. livingreviews.org/lrlr-2007-2 


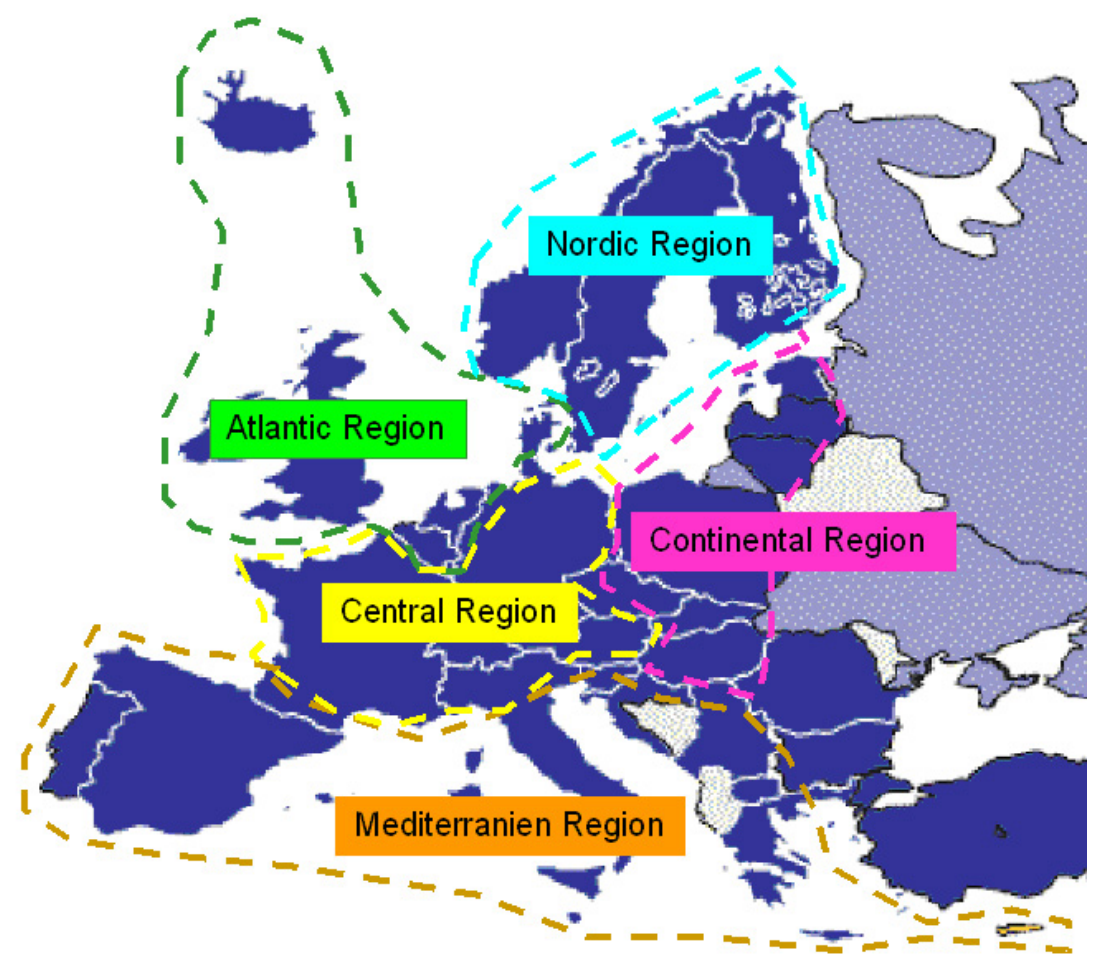

Figure 12: The European forest regions emerging from the analysis. 
recreational demands of different ethnic groups. In the Benelux countries and in the U.K. the combination of intensive recreation and nature conservation also poses a special challenge (Bruls et al., 2004; Roovers et al., 2004). Additional challenges for management are on the one hand the supply of recreation opportunities and conflict resolution between different user groups, crowding, and rubbish dumping. On the other hand the increasing demand for an open access to forests is of increasing relevance for recreation and tourism. Surveys and monitoring of visitor numbers, changing demands and efforts to ensure that there are accessible forest areas close to where people live are an integral aspect of forest management.

In the Nordic Region challenges are completely different. These countries contain an extremely high proportion of forest (up to 69\%). In Sweden, Norway, and Finland, multi-functional forestry must include the traditional "every man's rights" which include berry picking, mushroom collecting, and free access for all recreation and sports activities, which are considered of utmost importance by the entire population (Sievänen et al., 2004). The main conflicts are between forestry and recreation. Large clearcuts and road contruction are mentioned as major problems by many researchers and managers from these countries. Compared with these issues, the severity and frequency of other conflicts is considered to be rather low. Forest managers have to deal with an increasing number of conflicts with the use of snow mobiles in winter, unauthorised motorized camping and erosion caused by mountain biking. The management concepts differ across the various Nordic countries. While management in Finland is mainly based on a standardized method for visitor surveys there is no tradition in Norway for systematic collection of data and users of nature, except for national surveys organized by Statistics Norway. By contrast monitoring in Norway is primarily biological monitoring. Management has to deal with the precondition of free access. Therefore restrictive management actions such as limiting the number of visitors able to visit an area, or the use of entrance fees to ration visitor numbers are unlikely to be feasible, while softer actions such as visitor information, signposting and guided tours are more acceptable (Vistad, 2003). In the Nordic region increasing ecotourism is a new challenge for forest mangement.

In the countries of Central Europe, such as Germany, Switzerland, and Austria, as well as large areas of France, typically about one third of the area is under forest cover and all countries provide free access to the forest. Conflicts arise mainly between different user groups (for example between horse riders and cyclists, or cyclists and hikers) and between recreation demands and nature conservation priorities. Conflicts exist in areas with greater restrictions from nature conservation and they predominantly involve outdoor sports. These conflicts also occur in forests close to urban areas. In the mountain areas, off-piste skiing, back country skiing and snow shoeing as well as montain biking lead to conflicts. The planning of new recreational infrastructure has a long tradition in Central Europe. Visitor management is a constant challenge for managers, especially in and close to densely populated areas. Management and monitoring of recreation mainly occurs as an integrated task of forest inventory or management planning. Only in special cases is there independent planning for recreation and nature tourism. New forms of conflict resolution have been developed using contracts and voluntary agreements with sport associations, especially concerning rock climbing and cross-county skiing.

The Continental Region (i.e. Poland, the Baltic states, the Czech Republic, Slovakia and others) face a different set of challenges, partly as a result of the legacy of the Soviet or communist era, restitution of forest lands to their former owners and rural depopulation. Recreation has always been an important management concern, but frequently appropriate infrastructure, or controlled access may be absent. Many prerequisites for more intensive tourism use are also missing. The restructuring of agriculture, and the widespread conversion of arable land to shrubs and eventually to forests is leading to significant changes in the rural landscape. The main conflict area is between recreation and nature conservation. Most of the protected areas have been established in Eastern Europe during the last 20 or 30 years, many of them in traditional recreational locations, for example in Latvia and along the Baltic coast line and in mountainous areas. The mountainous areas

Living Reviews in Landscape Research

http://www. livingreviews.org/lrlr-2007-2 
of the Czech Republic, Slovakia and southern Poland are facing increasing problems, especially with ski touring, cross country skiing, snow shoeing and snow mobiles as well as climbing and mountain biking. The planning, management and monitoring systems are similar to those used in the Central region. They are mainly connected with forest inventory and management or with the management plans for protected areas. Around bigger cities and urban areas, the recreational planning as well as the management of the recreational infrastructure is more intensive. The most popular management actions used in these countries are restrictive ones, particularly rules and regulations, but also prohibitions, although their acceptance by the public appears to be rather low. Experts in the region also mentioned the education of future management personnel as a challenge, especially with regard to training in the areas of recreation and or eco-tourism. New challenges derive from the forest ownership transformation process in these countries.

The Mediterranean Region also contains about one third of its area as forest, but here it is different type of forest, often being sparse in terms of tree cover and composed of trees suited to the climate but which are also flammable. Timber production is not important so one of the main additional uses in forests is tourism, which requires landscapes of high aesthetic quality, and also leads to further demands such as fire management, the provision of recreational infrastructure, and the restoration of previously intensively used areas. Rubbish dumping by private individuals was mentioned by the experts as a "tradition" in almost all Mediterranean countries causing a lot of problems for forest management. Some areas are currently subject to intensive reforestation, or at least to the stabilization of marginal forests in semi-arid areas. All these activities also need to consider demands for nature conservation.

In most of the mediterranean countries there is no independent planning or monitoring of recreation and nature tourism in forests. In Greece and Italy, for example, recreational planning is mainly done in special cases, especially around larger cities to provide recreational opportunities. In Cyprus a close cooperation between the Cyprus Tourism Organization, the Forestry department and other stakeholders has fostered strategic planning and monitoring of forests, rural tourism and nature tourism projects. Future challenges were mainly seen in an increasing need for environmental education, new demands like "nature tourism" and the necessity for visitor monitoring.

\subsection{North America}

In the U.S.A., with a tradition of strong private property rights and no public access to private land, the main resources for outdoor recreation have, for a long time, been the public lands managed by the National Park Service, the U.S. Forest Service, the Bureau of Land Management (BLM) and the network of state parks managed by each state. Significant infrastructure development was put in place several decades ago and the period of the 1980s saw reductions in federal funding to these agencies. In the U.S.A., the population is set to increase as a result of immigration and the ethnic mix of the population is also expected to change so that patterns of leisure and recreation are likely to be different. Health concerns such as the "epidemic of obesity" and the need to increase the physical activity levels of the American population are also at the forefront of policies connected with outdoor recreation (Cordell, 2005). Meanwhile, the pressures placed on well-loved and accessible national parks such as Yosemite lead to severe conflicts of visitor numbers, activities and the protection and management of natural resources. There have traditionally been differences between the different management agencies, the National Park Service being concerned with scenery, nature and recreation management and therefore a more focused remit than the Forest Service or BLM which each have goals to develop and use a wide range of natural resources. This, such as timber cutting in old-growth forests of the Pacific North-west has led to conflicts over resource use and nature conservation, scenic preservation and recreation. Tools to manage visitors and visitor pressure have featured in the management systems of the agencies for some time and these continue to be developed and applied. One of the strong points of these approaches 


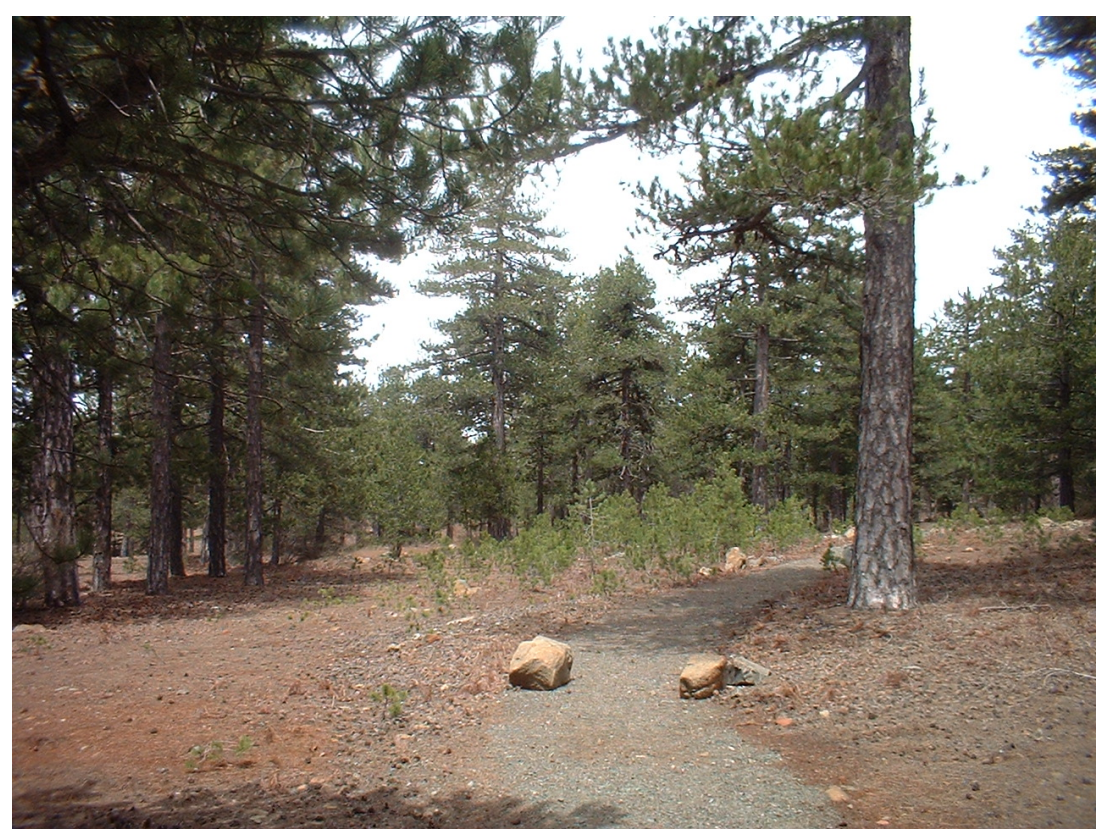

Figure 13: A path in the forests of the Troodos Mountains in Cyprus is linked to the nature tourism strategy of the country, part of an integrated approach.

such as the Recreation Opportunity Spectrum is to connect the nature of the visitor experience with the type of landscape setting within which this experience takes place. Another tool, Limits of Acceptable Change is used to manage the changes to the ecology that occur as a result of high levels of visitor use (Haider, 2004). In addition, given the popularity of motorised vehicles in the U.S.A., conflicts between these and the natural resources are a constant theme requiring management action and monitoring.

The U.S. Forest Service has a research programme that undertakes research in to provide information about recreation use of forests, supply and demand of recreation opportunities, and impacts of resource management activities and landscape change on recreation activities (USDA, 2006). A broad range of topics are studied including:

- Relationships between ecological conditions and recreation activities: impacts of fire on recreation activities.

- Cultural differences in outdoor recreation use: minority ethnic group participation in outdoor recreation; access to leisure and urban open space opportunities.

- Psychological and social dimensions of the recreation experience: human values and perceptions associated with recreation activities; sense of place and recreation management; experiential aspects of wilderness; impacts of criminal activity in forests on recreation; use of recreation fees; recreation visitor conflicts.

- Recreation assessment and trends: visitor service quality assessment; national recreation assessment and trend analysis (NSRE); national visitor use monitoring (NVUM); scenic quality assessment.

Many of these activities are reflected in the aspects described in earlier sections and demonstrate that many of the concerns are common to a wide range of areas around the world.

Living Reviews in Landscape Research

http://www. livingreviews.org/lrlr-2007-2 


\subsection{Principles of sustainable nature tourism}

Given the kinds of possible conflicts described above it is important to be able to develop sustainable methods for managing recreation and tourism. Metsähallitus, the state Forest and Park Service in Finland, is responsible for managing most of the country's protected areas as well as supplying partly the country's forest industry. The organisation has developed nine principles which summarise the key elements of managing sustainable nature tourism in protected areas (Metsähallitus, 2000):

1. Natural values should be preserved and all activities should promote nature conservation. Features are small groups; erosion and impacts monitored; nature is the prime reason for the visit; marked trails; tourism into area with suitable features; nature education and awareness are central.

2. The environment must be subjected to as little pressure as possible. Every effort is taken to avoid damage and disturbance; no trace of visitors should be left behind; emissions minimised and renewable energy sources preferred.

3. Local traditions, cultures and communities must be respected. Visitors are encouraged to learn about the communities and cultures in the area; local communities are considered in the provision of information and activities; guides familiar with local conditions.

4. Visitors should increase their understanding and appreciation of nature and cultures. Information should be available prior to the visit; information available on arrival, guides well trained; information and interpretation easily accessible and attractive; visitors are able to contribute to the management of the area.

5. Improved recreational facilities must be provided for visitors. Needs of visitors considered; facilities to suit demand and conditions; visitors to enjoy peace and quiet as well as guided activities; facilities and services developed in cooperation with local businesses.

6. Visitors should be encouraged to enjoy both mental and physical recreation. Facilities provided for range of visitors. i.e. hikers and bikers as well as casual recreational walkers; easy and demanding routes available; opportunities for a variety of activities in natural surroundings.

7. Local economies and employment must be promoted. Local businesses to be used wherever possible; employment given to local people wherever possible.

8. Publicity materials should be produced responsibly and carefully. Information must be reliable and up-to-date; publicity is conducted openly and interactively and does not work against nature conservation.

9. Activities must be planned and organised co-operatively. Visitor's opinions are important; training organised with local businesses; all stakeholders involved in planning.

In developing a nature tourism operation, it is essential to clearly identify the destination and to have a unique selling point. The natural assets of a destination play an increasingly important part in presenting and marketing a tourism experience (Buckley, 2001). If an area is listed as a World Heritage Site, for example, this indicates globally outstanding natural and/or cultural significance. This can potentially cause conflicts where an increased number of visitors cause intense pressure on the infrastructure and support services within the area. Eagles et al. (2000) estimated that in 1996, there were more than 2.6 billion visitor days of recreation activity in the parks and protected 


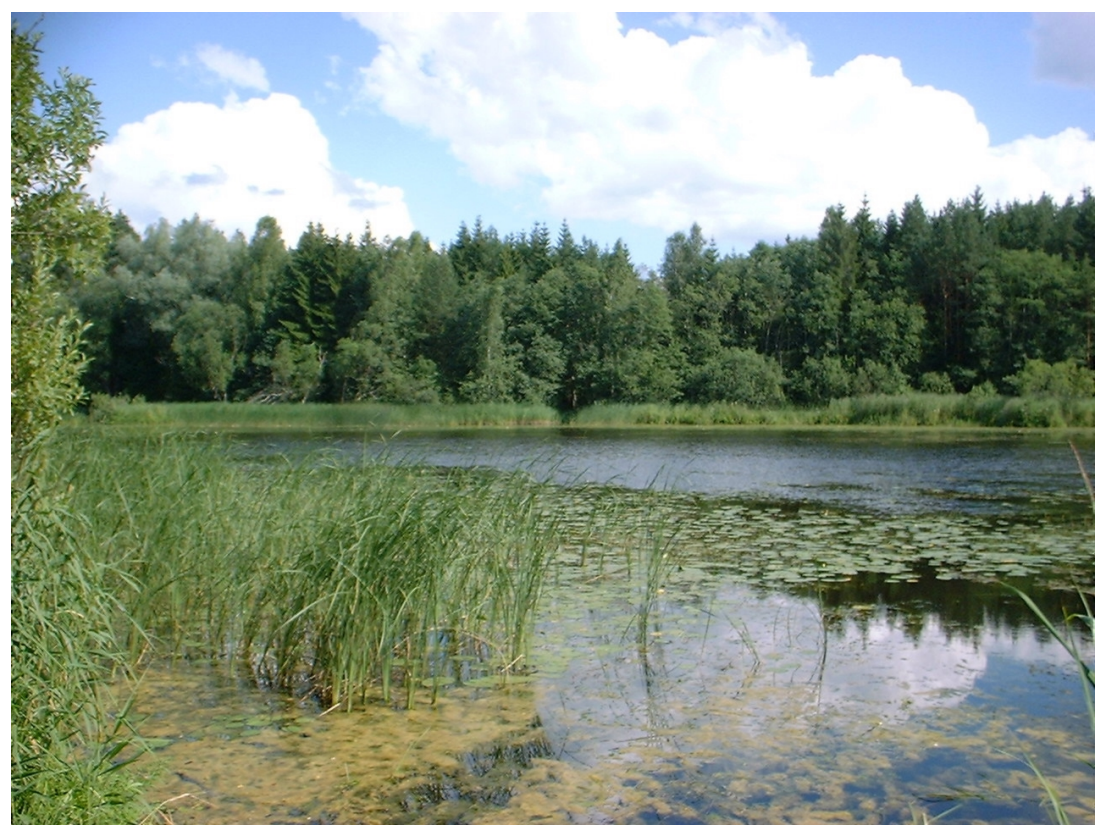

Figure 14: A lake in Latvia with a very natural structure and unpolluted water is ideal for bird watching.

areas of Canada and the U.S.A. This level of activity is likely to have major economic, social and environmental impacts.

It is essential to develop partnerships between tourism, environmental and community interests. These partnerships all need to have a shared understanding of the processes and benefits but also of the commitments entailed. A large number of Codes of Conduct for tourism have been developed by a range of organizations regarding environmental, socio-cultural and political features and behaviour. Many of these are pertinent to nature tourism: the World Tourism Organisation of the UN Global Code of Ethics for Tourism (World Tourism Organization, 2001); the United Nations Environment Programme Principles on the Implementation of Sustainable Tourism (UNEP, 2000); the World Wildlife Fund (WWF) Ten Principles for Mediterranean Tourism; the Pacific Asia Travel Association (PATA) Code for Environmentally Responsible Tourism; the WWF Guidelines for Community-Based Ecotourism Development (WWF, 2001), and the Environmental Guidelines of the World Travel and Tourism Council (WTTC, 1998). These codes are designed to ensure that all the actors involved understand what is trying to be achieved but also that everyone is working towards the same process and goal. Within the codes, issues such as waste disposal, disturbance to wildlife and habitats, respecting cultures, supporting education and complying with the country's safety standards, are covered.

To be successful and to retain the support of the local community, any nature tourism operations have to provide economic benefits. It is important that these benefits are shared with the community and not all taken out of the area. Parks often supply the most important part of the nature tourism experience, but typically capture little of the value of the stream of economic benefits (Wells, 1997).

Nature tourism depends on a high quality environment to attract visitors. As a result, the negative effects of tourism need to be minimised. This will also help to reduce conflict with local communities. Moreover, nature tourism should contribute actively to the conservation of natural and cultural heritage. If the area is allowed to degrade, either through lack of management or through over-exploitation, then the area will lose its attractiveness to visitors (Newsome et al.,

Living Reviews in Landscape Research

http://www.livingreviews.org/lrlr-2007-2 
2002). The direct impacts of tourists, such as trampling and litter, have been fairly extensively studied. However, impacts which are more diffuse, indirect and intermittent which are difficult and expensive to measure such as waterborne pathogens or interference with plant pollination ecology are less well-understood (Buckley, 2001). To reduce conflicts and tensions between local populations and tourists, it is imperative that these effects are also considered and researched.

To be sustainable, it is important that any nature tourism development encourages community involvement and participation. Local and indigenous communities should be included in planning, development and operation (Denman, 2002). Local people should be involved from the outset, at the planning stage right through to gaining the economic benefits of the operation as a result of employment generated by the project or by being key stakeholders. However, one of the problems of local community participation is that it can be difficult for it to be equal. Some people choose not to participate (Ghimire and Pimbert, 1997) or it may not be possible for some to participate so that they benefit economically. One of the key problems is that tourism may not actually link well enough to local communities dependent on natural resources and traditional rural livelihoods. Ghimire and Pimbert (1997) have presented a six-part typology of participation ranging from passive participation where people are told what will happen with no input to decisions to interactive participation where people are involved in joint analysis where new local groups are formed or strengthened and they take control over local decisions and practices (this parcipation ladder is quite frequent in participatory planning research).

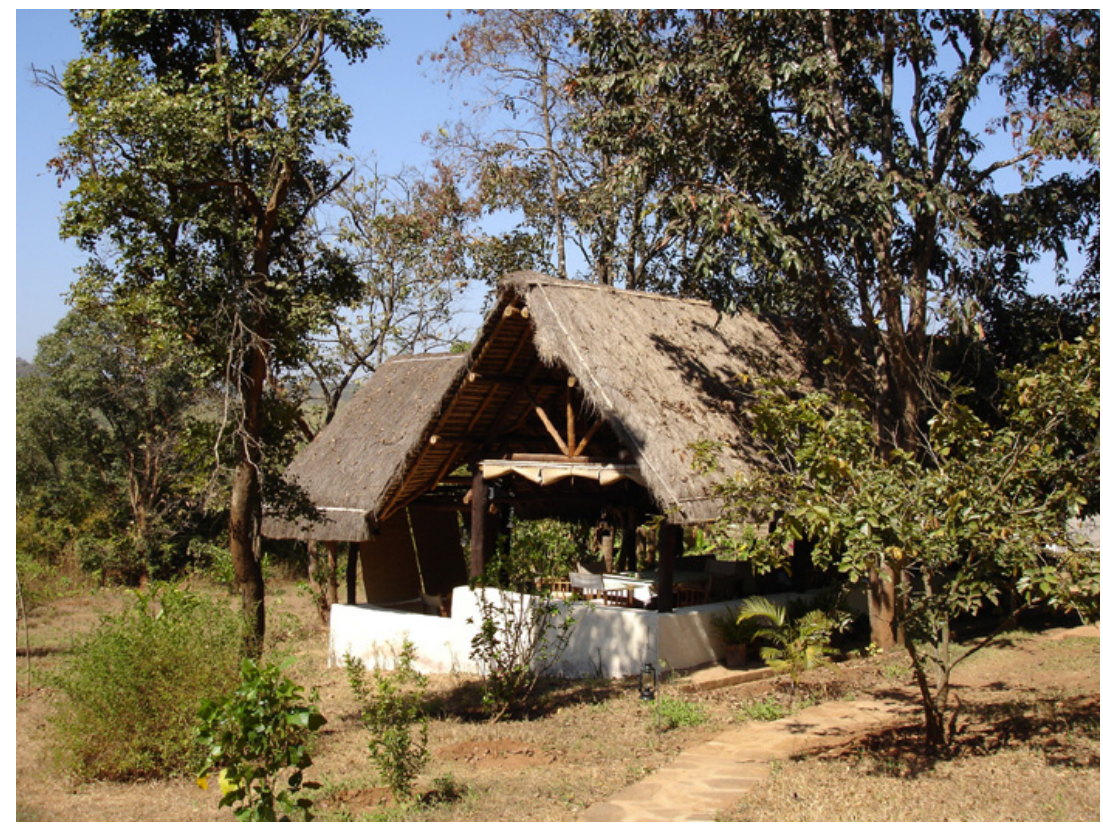

Figure 15: Accommodation at an ecotourist lodge in the Western Ghats of India has been developed with sustainable principles in mind and provides employment for local people.

All stakeholders should be encouraged to engage in the planning process and in liaison between tourism enterprises, government bodies and environmental planners. Participatory management is a key tool in ensuring participation in planning, decision-making and management (Denman, 2002). One important task is to develop tools and approaches to improve integrating local knowledge into decision making and planning processes. In developing countries especially, it is important to encourage management styles based upon local rules and collective action. This should ensure long-term preservation of national resources as well as a sustained supply of resources required by 
nature tourists.

\subsection{Management of nature tourism}

A number of indicators have been developed to enable tourism stakeholders and nature tourism operators to assess the sustainability of their activities. These cover issues such as the well-being of host communities, tourist satisfaction and management of scarce resources. For example, the World Tourism Organisation produced a book entitled Indicators of Sustainable Development for Tourism Destinations in 2004 (World Tourism Organization, 2004), the Department for Culture, Media and Sport (DCMS) produced National Sustainable Tourism Indicators in 2001 (DCMS, 2001) and the Association of Caribbean States (ACS) have developed a set of indicators that are quantifiable and applicable through a Tourism Sustainability Index in order to create a Sustainable Tourism Zone for the Caribbean (Simpson and Ladle, 2007). When developing new areas for Nature Tourism, it is important to consider the carrying capacity of the area, not only in terms of the local community but also for the visitors. Natural areas are often diverse landscapes with a number of features attractive to different groups of people for different reasons. However, diversity often leads to conflict, where visitors who are seeking different experiences find themselves in the same setting. In the future conflicts will increase between clients seeking for peace and quietness in the wilderness and clients interested in motorised outdoor activities.

Eagles (2001) suggests that the negative impact of tourism on park resources is less influenced by absolute numbers of visitors, and more influenced by weak tourism policy, management and staffing often caused by very low levels of finance. Managers of protected areas worldwide face the challenge of conserving natural and cultural heritage for future generations, ensuring that conservation values are not degraded by the current generation's use and appreciation of these areas (Buckley, 2001). There is a danger that, by identifying and promoting prominent natural areas for tourism, the numbers visiting and their associated impacts can actually degrade what most people value in the area. Visitor use can negatively affect the environment as well as the quality of visitor experiences. In order to improve any services offered, ensure all stakeholders are satisfied and the integrity of the environment is maintained, it is essential that strategies and impacts are monitored, evaluated and reviewed (World Tourism Organization, 2004). It is also important to undertake market research on the visitors to assess their satisfaction with the area and facilities. This will enable the development of pragmatic and effective recommendations for addressing any existing and future problems.

Living Reviews in Landscape Research

http://www. livingreviews.org/lrlr-2007-2 


\section{Conclusions and research needs for the future}

This review paper has presented a wide range of issues that are of concern to policy makers, planners and researchers at the present time. Given the fast changing social, economic and demographic conditions as well as the increasing pressures on the environment and the uncertainties around climate change, the subject of outdoor recreation and nature tourism is one that needs to be kept continually under review. It is clear that a societies develop, economies mature and people around the world become more affluent, live longer and have more spare time recreation and tourism become increasingly important activities. The statistics for the growth of outdoor recreation and nature tourism reinforce this importance. The review also demonstrates that many of the drivers of changing levels and types of demand are not completely predictable and that considerable uncertainties exist in terms of which drivers will continue to have an effect and which may weaken over time. The nature of the impact of new technology is also uncertain but it is likely to be large in scale.

In the light of the analysis of trends identified above, what are the research needs for the future? Each section of the paper has examined different facets of outdoor recreation and nature tourism and as a result is able to generate a number of research needs:

\subsection{The drivers of recreation}

As a result of the discussion of the drivers of recreation there are needs for research to strengthen the base assumptions and to validate the trends as they emerge over the next years. For this a series of baseline studies from a range of countries followed up by longitudinal surveys conducted every 5-10 years would help policy makers and planners in the development of their policies and plans. The discussion on demand monitoring, which is an essential aspect of this kind of study also throws up several important lines of research:

- Systematic monitoring of the recreation behaviour of the population - national level recreation surveys - sampling individuals or households.

- Systematic recreation monitoring on-site, site specific visitor assessment and visitor surveys.

- Harmonization of key variables for international comparisons.

- Harmonization of methods for national statistics over time, trend construction, forecast modelling to allow international comparison, especially at the pan-European level.

- Development of methodology to suit the changing society: the use of internet survey, GPStracking etc.

- Pressure on natural resources and conflict management because of new activities and technologies such as motorised recreation in Europe.

- Recreation opportunities and environmental changes such as climate change, rural landscapes disturbed by afforestation or uncontrolled housing development, poor quality of water resources.

- The increasing number of people enjoying nature tourism trips shows no signs of abating and, if predictions are to be believed, numbers will only continue to rise. As a result, policy makers, planners and managers are going to have to deal with increasing demand so that instruments to evaluate and plan for this are needed. 


\subsection{Health and well-being}

This short review of the potential effects of nature on health and well-being shows that the evidence base is increasing but is not strong enough to have a major impact on policy. Gaps in research were identified in a research mapping study carried out for the U.K. department of Communities and Local Government (Bell et al., 2006) which showed that this area has as yet a patchy research record throughout the developed world. Some priorities for research were suggested, in relation to a number of themes such as:

Economic values:

- Funding mechanisms for green space

- The value of economic regeneration

- Quantification in monetary terms of health benefits (of exercise etc.) e.g. savings to the health budget

- Costs of crime and vandalism

- The value of local employment provided by green space

Health:

- Benefits in relation to key target groups, especially children, older people and disabled people.

- Longitudinal studies to test and validate health benefits over time

- Barriers to the use of green space for health and well-being

- The effects of risk aversion on levels of use of green space for health and well-being

Social and community:

- The availability of nearby green space for children's play

- Intergenerational studies into play and the use of green space, as affected by, constrained or encouraged by parents or grandparents

- The effects of fear and feeling unsafe as barriers to using spaces of different types by different social groups.

- The difference between actual and perceived levels of crime in different spaces

- The social setting of crime

- Planting for safety

- The use of lighting to increase levels of use and to reduce fear.

Physical aspects

- Accessibilty to green spaces "from the front door" in order to reduce the need to use transport

Management and maintenance

- Maintenance of informal green spaces used a lot for play

- What skills are needed by staff to prepare for current and future demands of management and maintenance

- Methods of communication and information provision to the wide range of user groups in different spaces as a means of helping to raise awareness, build confidence and manage risk and fear. 


\subsection{Conflicts between recreation and nature tourism on sustainable use of resources and environments}

In the area of conflicts between visitors and the environment the following needs have been identified:

- To ensure that visitors have as minimal impact as possible it will be necessary to continue gathering information on the intensity of recreational use that is made on areas and also to assess the way they behave during their visits. By having a greater understanding of the benefits gained by individuals of access to natural areas, it will allow planners and managers to focus their activities and operations more effectively.

- Climate change is perhaps the biggest threat to nature tourism. However, it is an issue that is beyond the control of recreation and nature tourism planners. Those involved will need to conduct research into the impacts climate change could have on the environment and businesses in a range of habitats and regions. It is also important to understand how to adapt to the changing conditions. Ideally, recreation and nature tourism operators should also implement mitigation plans so that impact is reduced initially.

- Nature tourism's continued expansion offers opportunities to generate increased income and employment, both nationally and in remote rural areas, and to provide increased incentives for biodiversity conservation in state protected areas and on private lands (Wells, 1997). However, these must be balanced with the risks of continued environmental degradation and greater pressure on protected areas, many of which lack the resources for effective management and are unprepared for significant growth in visitor numbers (Wells, 1997).

- The development and application of visitor management systems to different regions and for different circumstances will help to provide planners and managers with more sophisticated and sensitive tools than they have at present.

- Techniques need to be further developed to enable existing areas to deal with increased pressures. This may include setting limits on visitor numbers or activities to ensure the environment remains undamaged.

- Research into the use of technological advancements, so that the development of additional tourism areas will have less of an impact on the environment and to ensure the sustainability of the venture in the long-term.

- For some of the conflicts identified, general research is required. However, for certain issues, research and information needs to be more specific to the region, area or people. For example, reducing conflicts between local people and nature tourists will be region and resource specific. It is possible to identify common themes, such as participation, but as each community is unique, applying general guidelines will also be problematic.

The research in the field described here is increasing all the time and new findings about all the subjects discussed here constantly emerge. It is the intention to keep this review itself under review and to revisit it when significant new material affects the conclusions and predictions. 


\section{References}

Aasetre, J., Vistad, O.I. (2006), "Forests and 'friluftsliv' in Norway", conference paper. Related online version (cited on 7 May 2007):

http://www.openspace.eca.ac.uk/costE33/outputs_northerneurope.htm. 1

Ashcroft, P. (2002), "Case study: Walking the Way to Health Initiative. Summary of papers", National Conference Greenspace and Healthy Living, 14 May 2002, Manchester, conference paper. 3

Ashley, C., Boyd, C., Goodwin, H. (2000), Pro-poor Tourism: Putting Poverty at the Heart of the Tourism Agenda, vol. 51 of Natural Resource Perspectives, London (Overseas Development Institute). URL (cited on 7 May 2007):

http://www.odi.org.uk/NRP/51.html. 2.7

Bell, S. (1997), Design for Outdoor Recreation, London; New York (E \& FN Spon). 1, 4.1

Bell, S., Ward Thompson, C., Findlay, C., Montarzino, A., Morris, N. (2005), "Self Reported Stress Reduction by Users of Woodlands", in Forests, Trees, and Human Health and Well-Being, (Ed.) Gallis, C.T., Proceedings of the 1st COST E39 Conference, October 2005, Thessaloniki, pp. 71-80, Thessaloniki (SIOKIS Medical \& Scientific Publishers). Related online version (cited on 23 April 2007):

http://www.e39.ee/en/m-51/c-38/. 3

Bell, S., Montarzino, A., Travlou, P. (2006), "Green and Public Space Research: Mapping and Priorities", London (Department for Communities and Local Government). URL (cited on 23 April 2007):

http://www. communities.gov.uk/index.asp?id=1500480. 5.2

Bruls, E., Busser, M., Tuunter, E. (2004), 'Jewels in the crown': Good practices Natura 2000 and leisure, Den Haag (Stichting Recreatie). Related online version (cited on 9 May 2007): http://ec.europa.eu/environment/nature/nature_conservation/useful_info/ documents_publications/pdf/jewels_in_the_crown.pdf. 4.1

Buckley, R. (Ed.) (2001), Fenner Conference 2001 (Abstracts), Nature Tourism and the Environment, Canberra, 3-6 September 2001, Canberra (Australian Academy of Science). Related online version (cited on 7 November 2006):

http: //www. crctourism. com.au/CRCBookshop/page. aspx?page_id=2\&productID=346. 4.3, $4.3,4.4$

Buckley, R. (2003), "The Practice and Politics of Tourism and Land Management", in Nature-based Tourism, Environment and Land Management, (Eds.) R., Buckley, C., Pickering, D.B., Weaver, Papers presented at the Fenner Conference on Nature Tourism and the Environment, held in Canberra, Australia, 2001, Wallingford; Cambridge (CABI Publishing). 2.7

Burgess, J. (1995), "Growing in confidence: a study of perceptions of risk in urban fringe woodlands", CCP 457, Cheltenham (Countryside Commission). 3

Carr, E. (2006), National Parks and the Modern Movement in the USA, Ph.D. Thesis, Edinburgh College of Art, Edinburgh. 1

Cordell, H.K. (2004), Outdoor Recreation for the 21st Century: A Report to the Nation. The National Survey on Recreation and the Environment, State College, PA (Venture Publishing). $2.3,2.5,3,4$

Living Reviews in Landscape Research

http://www. livingreviews . org/lrlr-2007-2 
Cordell, H.K. (2005), "Recreation and Tourism Trends Research", National Outdoor Recreation Conference, Helsinki, Finland, 10 November 2005, conference paper. Related online version (cited on 10 November 2006):

http://www.srs.fs.fed.us/trends/NatORC.html. 1.1, 2.1, 2.5, 2.5, 4, 4.2

Cordell, H.K., Teasley, R.J., Super, G., Bergstrom, J.C., McDonald, B. (1997), "Outdoor Recreation in the United States: Results from the National Survey on Recreation and the Environment, Chapter 2: Outdoor Recreation Participation", Athens, GA (USDA Forest Service). Related online version (cited on 7 May 2007): http://www.srs.fs.usda.gov/trends/fsoutrec.html. 1, 3

Cordell, H.K., Betz, C., Bowker, J.M., English, D.B.K., Mou, S.H., Bergstrom, J.C., Teasley, R.J., Tarrant, M.A., Loomis, J. (1999), Outdoor Recreation in American Life: A National Assessment of Demand and Supply Trends, Champaign, IL (Sagamore Publishing). 2.3, 2.5

OPENspace Research Centre (2004a), "COST Action E33 (Forest Recreation and Nature Tourism): Objectives", online resource. URL (cited on 5 November 2006):

http://www.openspace.eca.ac.uk/costE33/objectives.htm. 2.7, 2.7

OPENspace Research Centre (2004b), "Cost Action E33: Forest Recreation and Nature Tourism", project homepage. URL (cited on 26 November 2006):

http://www.openspace.eca.ac.uk/costE33/homepage.htm. 1.1

Crick, H.Q.P, Dudley, C., Glue, D.E., D.L., Thomson (1997), "UK birds are laying eggs earlier", Nature, 388: 526. 2.2

Dales, B. (2004), "New access rights and responsibilities in Scotland", conference paper. Related online version (cited on 7 May 2007):

http://www.openspace.eca.ac.uk/costE33/outputs_scotland.htm. 1

DCMS (2001), "National Sustainable Tourism Indicators: Monitoring progress towards sustainable tourism in England", London (Department of Culture, Media and Sport (DCMS)). Related online version (cited on 7 November 2006):

http://www . culture.gov.uk/NR/rdonlyres/F73BEAA1-B017-4C34-BE75-8C47A127C486/0/ NationalSustainableTourismIndicators.doc. 4.4

de Vries, S. (2000), "Regional Differences in the Demand for and Supply of Nature-Based Recreation within the Netherlands", in Forests and Society: The Role of Research, Vol. 1: Sub-Plenary Sessions, (Ed.) Krishnapillay, B. et al., Proceedings of the XXI IUFRO World Congress, 7-12 August 2000, Kuala Lumpur, Malaysia, pp. 662-673, Vienna; Kuala Lumpur (IUFRO; FRIM). Related online version (cited on 7 May 2007): http://iufro-down.boku.ac.at/iufro/congress/congress2000/csc/vol1.pdf. 3

de Vries, S., Verheij, R.A., Groenewegen, P.P., Spreeuwenberg, P. (2003), "Natural environments healthy environments? An exploratory analysis of the relationship between nature and health", Environment and Planning A, 35(10): 1717-1731, doi:10.1068/a35111. 3

Denman, R. et al. (Ed.) (2002), The World Ecotourism Summit, Québec City, Canada from 19-22 May, 2002, Madrid; Paris (World Tourism Organization; UNEP). URL (cited on 6 November 2006):

http://www.world-tourism.org/sustainable/IYE/quebec/. 4.3, 4.3

DuWors, E., Villeneuve, M., Filion, F.L., Reid, R., Bouchard, P., Legg, D., Boxall, P., Williamson, T., Bath, A., Meiss, S. (1999), "The Importance of Nature to Canadians: Survey Highlights", 
Ottawa, ON (Environment Canada). Related online version (cited on 7 May 2007):

http://www.ec.gc.ca/nature/highlights/highlite.html. 2.3, 1

Eagles, P.F.J (2001), "International Trends in Park Tourism", EUROPARC 2001, October 3-7, 2001, Hohe Tauern National Park, Matrei, Austria, conference paper. Related online version (cited on 7 November 2006):

http://www.ahs.uwaterloo.ca/rec/pdf/inttrends.pdf. 2.2, 4.4

Eagles, P.F.J., McLean, D., Stabler, M.J. (2000), "Estimating the Tourism Volume and Value in Parks and Protected Areas in Canada and the USA", George Wright Forum, 17(3): 62-76. Related online version (cited on 7 May 2007):

http://www.georgewright.org/173eagles.pdf. 4.3

English, D.B.K., Kocis, S.M., Ross Arnold, J., Zarnoch, S.J., Warren, L. (2002), "Visitor Use of USDA Forest Service Recreation Areas: Methods and Results from the National Visitor Use Monitoring Effort", in Monitoring and Management of Visitor Flows in Recreational and Protected Areas, (Eds.) Arnberger, A., Brandenburg, C., Muhar, A., Proceedings of the conference held at University of Natural Resources and Applied Life Sciences (BOKU), Vienna, Austria, January 30 - February 02, 2002, pp. 246-251, Vienna (BOKU/ILA). 2.4

Erkkonen, J., Sievänen, T. (2002), "Standardisation of visitor surveys: Experiences from Finland", in Monitoring and Management of Visitor Flows in Recreational and Protected Areas, (Eds.) Arnberger, A., Brandenburg, C., Muhar, A., Proceedings of the conference held at University of Natural Resources and Applied Life Sciences (BOKU), Vienna, Austria, January 30 - February 02, 2002, pp. 252-257, Vienna (BOKU/ILA). 2.4

ETC (2006), "Tourism Trends for Europe", Brussels (European Travel Commission). Related online version (cited on 7 November 2006):

http: //www.etc-corporate.org/modules . php?name=Content\&pa=showpage\&pid=100. 2.1, 2.2

European Commission (2000), "Towards Quality Rural Tourism: Integrated Quality Management (IQM) of Rural Destinations", Brussels (European Commission). Related online version (cited on 6 November 2006):

http://ec.europa.eu/enterprise/services/tourism/studies_and_publications.htm. 2.7

European Commission (2006), "Eurostat", institutional homepage. URL (cited on 26 November 2006):

http://epp.eurostat.ec.europa.eu. 2.1

Ghimire, K.B., Pimbert, M.P. (1997), Social change and Conservation: Environmental Politics and Impacts of National Parks and Protected Areas, London (Earthscan Publications). 4.3

Grahn, P., Stigsdotter, U.A. (2003), "Landscape planning and stress", Urban Forestry \& Urban Greening, 2(1): 1-18, doi:10.1078/1618-8667-00019. 3, 3

Grimsditch, G.D., Salm, R.V. (2006), IUCN Resilience Science Group Working Paper Series, 1, Gland, Switzerland (The World Conservation Union (IUCN)). URL (cited on 23 April 2007): http://www.iucn.org/themes/marine/pubs/pubs.htm. 2.2

Haider, W. (2004), "Visitor management frameworks in North America", 2nd Management Committee meeting and WGs meeting and Workshop in Edinburgh, Scotland, 31 October - 2 November 2004, conference paper. Related online version (cited on 26 November 2006): http://www.openspace.eca.ac.uk/coste33/outputs_presentations.htm. 4.2 
Halpenny, E., Otte, N.R. (1999), "Not just nature", Our Planet, 1999(10.1). Related online version (cited on 5 November 2006):

http://www.ourplanet.com/imgversn/101/otte.html. 2.6

Hartig, T., Mang, M., Evans, G.W. (1991), "Restorative Effects of Natural Environment Experiences", Environment and Behaviour, 23: 3-26, doi:10.1177/0013916591231001. 1. 3

Hartig, T., Böök, A., Garvill, J., Olsson, T., Gärling, T. (1996), "Environmental influences on psychological restoration", Scandinavian Journal of Psychology, 37: 378-393. 3

Henley Centre (2005), "Paper 2: Demand for outdoor recreation. A report for Natural England's outdoor recreation strategy", London (Henley Centre/Headlight Vision). Related online version (cited on 7 May 2007):

http://www. countryside.gov.uk/LAR/Recreation/strategy_research.asp. 2

Heytze, H., Herbert, L. (1990), "Landscape experience in poplar forests", in Proceedings of the XIXth IUFRO World Congress, Montréal, Canada, August 5-11, 1990, pp. 47-60, Hull, QC (IUFRO). 4.1

Jensen, F.S., Koch, N.E. (1997), Frilutsliv i skovene 1976/77 - 1993/94, vol. 20 of Forskningserien, Hørsholm (Forskiningscentret for Skov \& Landskap). 2.3, 1, 2.4

Jensen, F.S., Koch, N.E. (2004), "Twenty-five Years of Forest Recreation Research in Denmark and its Influence on Forest Policy", Scandinavian Journal of Forest Research, 19(4): 93-102, doi:10.1080/14004080410034173. 2.3

Jepson, R. (2005), "Country Report UK for Cost E39: Forests, Trees and Human Health and Wellbeing", Brussels (COST). Related online version (cited on 7 May 2007):

http://www.e39.ee/en/countries/c-64/. 1

Kajala, L. (Ed.) (2006), Monitoring Outdoor Recreation in the Nordic and Baltic Countries, vol. 2006:530 of TemaNord, Copenhagen (Nordic Council of Ministers). Related online version (cited on 7 May 2007):

http://www . norden .org/pub/sk/showpub . asp?pubnr=2006:530. 2.4

Kajala, L., Almik, A., Dahl, R., Dikšaite, L., Erkkonen, J., Fredman, P., Jensen, F.S., Karoles, K., Sievänen, T., Skov-Petersen, H., Vistad, O.I., Wallsten, P. (2007), Visitor monitoring in nature areas - a manual based on experiences from the Nordic and Baltic countries, TemaNord, Copenhagen (Nordic Council of Ministers). Forthcoming. 2.4

Korpela, K., Hartig, T. (1996), "Restorative qualities of favourite places", Journal of Environmental Psychology, 16: 221-233. 3

Korpela, K., Sarjala, T. (2005), "Country Report Finland for Cost E39: Forests, Trees and Human Health and Wellbeing", Brussels (COST). Related online version (cited on 7 May 2007): http://www.e39.ee/en/countries/c-39/. 1

Kweon, B.-S., Sullivan, W.C., Wiley, A.R. (1998), "Green Common Spaces and the Social Integration of Inner City Older Adults", Environment and Behaviour, 30(6): 832-858, doi: 10.1177/001391659803000605. 3

Lindhagen, A., Hörnsten, L. (1998), "Changes in forest recreation between 1977 and 1997 - a study of public preferences and behaviour in Sweden", in Proceedings of AISF-EFI International Conference on Forest Management in Designated Conservation \& Recreation Areas, 7-11 October 1998, Florence, Italy, pp. 105-114, Padua (University of Padua Press). 2.5 
Maas, J., Verheij, R.A., Groenewegen, P.P., de Vries, S., Spreeuwenberg, P. (2006), "Green space, urbanity, and health: how strong is the relation?", Journal of Epidemiology and Community Health, 60: 587-592, doi:10.1136/jech.2005.043125. 3

MacDonald, D., Crabtree, J.R., Wiesinger, G., Dax, T., Stamous, N., Fleury, P., Gutierrez Lazpita, J., Gibon, A. (2000), "Agricultural abandonment in mountain areas of Europe: Environmental consequences and policy response", Journal of Environmental Management, 59(1): 47-69. 2.2

Maetzold, J.A. (2002), "Nature-Based Tourism and Agritourism Trends: Unlimited Opportunities", in Future Farms 2002: A Supermarket of Ideas, 15-16 November 2002, Norman, Oklahoma, pp. 84-89, Poteau, OK (Kerr Centre for Sustainable Agriculture). Related online version (cited on 7 November 2006):

http://www.kerrcenter.com/publications/2002_proceedings/futurefarms_2002.html.

$2.1,2.2$

Mastny, L. (2001), Traveling Light: New Paths for International Tourism, vol. 159 of Worldwatch Papers, Washington, DC (Worldwatch Institute). 2.6

McCormack, A.G., O'Leary, T. (1995), "A performance approach to the assessment of the aesthetic resources of forest parks by landscape experts", in Multiple Use and Environmental Values in Forest Planning, (Eds.) Hyttinen, P., Kähkönen, A., Pelli, P., Proceedings of the International Summer Course, Tohmajärvi, Finland, 5-10 June 1995, vol. 4 of EFI Proceedings, pp. 153-168, Joensuu (European Forest Institute). 4.1

Menzel, A., Fabian, P. (1999), "Growing season extended in Europe", Nature, 397: 659, doi: 10.1038/17709. 2.2

Metsähallitus (2000), Nature Protection Publications of the Finnish Forest and Park Service. Series B, 54, Helsinki (Metsähallitus). URL (cited on 7 May 2007):

http://www.metsa.fi/julkaisut/pdf/luo/b052.pdf. 4.3

Metsähallitus (2006), "Metsähallitus Website", institutional homepage. URL (cited on 5 November 2006):

http://www.metsa.fi. 2

Morris, N. (2003), "Health, Well-Being and Open Space: Literature Review", online resource, OPENspace Research Centre. URL (cited on 27 April 2007):

http://www.openspace.eca.ac.uk/literaturereview.htm. 3

Newsome, D., Moore, S.A., Dowling, R.K. (2002), Natural area tourism: Ecology, impacts and management, Clevedon; Buffalo (Channel View Publications). 2.6, 4.3

NSRE (2003), "National Survey on Recreation and the Environment 2000-2002 (Interagency National Survey Consortium): American's participation in Outdoor Recreation: Results from NSRE", Athens, GA; Knoxville, TN (USDA Forest Service; University of Tennessee). Related online version (cited on 10 November 2006):

http://www.srs.fs.usda.gov/trends/Nsre/nsre2.html. 2.3, 2.5, 3

NUFU (1999), Trees and Healthy Living, Proceedings of a National Conference, Wolverhampton, UK, 17 November 1999, Wolverhampton (National Urban Forestry Unit (NUFU)). 3

O’Brien, L. (2005), “Trees and woodlands: Nature's health service”, Farnham (Forest Research). Related online version (cited on 7 November 2006):

http://wWw.forestresearch.gov.uk/forestry/INFD-6J9GC4. 3

Living Reviews in Landscape Research

http://www. livingreviews.org/lrlr-2007-2 
Parsons, R., Tassinary, L.G., Ulrich, R.S., Hebl, M.R., Grossman-Alexander, M. (1998), "The view from the road: Implications for stress recovery and immunization", Journal of Environmental Psychology, 18: 113-140, doi:10.1006/jevp.1998.0086. 3

Pröbstl, U. (2005), "Forests in Balance? Forests under the spell of economical, ecological and recreational requirements - Considerations about the European Model", Allgemeine Forst- und Jagdzeitung, 178(4): 68-73. 4.1

Pröbstl, U., Wirth, V., Elands, B., Bell, S. (2007), Recreation and nature based tourism in European forests, Berlin (Springer Science). In preparation. 4.1, 4.1

Rauhala, J., Erkkonen, J., Iisalo, H. (2002), "Standardisation of visitor counting - Experiences from Finland", in Monitoring and Management of Visitor Flows in Recreational and Protected Areas, (Eds.) Arnberger, A., Brandenburg, C., Muhar, Proceedings of the conference held at University of Natural Resources and Applied Life Sciences (BOKU), Vienna, Austria, January 30 - February 02, 2002, pp. 258-263, Vienna (BOKU/ILA). 2.4

Roovers, P., Verheyen, K., Hermy, M., Gulinck, H. (2004), "Experimental trampling and vegetation recovery in some common forest and heath communities", Applied Vegetation Science, 7(1): 111118. 4.1

Salafsky, N., Wollenberg, E. (2000), "Linking Livelihoods and Conservation: A Conceptual Framework and Scale for Assessing the Integration of Human Needs and Biodiversity", World Development, 28: 1421-1438, doi:10.1016/S0305-750X(00)00031-0. 2.7

Sandur, H., Lepp, K., Soon, A., Maikov, K. (2005), "Country Report Estonia for Cost E39: Forests, Trees and Human Health and Wellbeing", Brussels (COST). Related online version (cited on 7 May 2007):

http://www.e39.ee/en/countries/c-26/. 1

Scrintzi, G., Tosi, V., Agatea, P., Flamminj, T. (1995), "Gli Italiani e il bosco. Coordinate qualiquantitaitve dell'utenza turistica in Italia. (Italians and the woods. The forest recreation demand in Italy)", ISAFA Comunicazioni di ricerca, 95(1). Related online version (cited on 7 May 2007): http://www.isafa.it/scientifica/pubblicazioni/pubblicazioni.htm. 2.3, 1

Seeland, K., Moser, K., Scheuthle, H., Kaiser, F.G. (2002), "Public acceptance of restrictions imposed on recreational activities in the peri-urban Nature Reserve Sihlwald, Switzerland", Urban Forestry \& Urban Greening, 1(1): 49-57, doi:10.1078/1618-8667-00006. 3

Selwyn, N. (2005), "Review Essay: Studying the Information Society", Information Society, 21/1: 77-79, doi:10.1080/01972240590895964. 2.1

Sievänen, T. (Ed.) (2001), Luonnon virkistyskäyttö 2000 (Outdoor recreation 2000), vol. 802 of Metsäntutkimuslaitoksen tiedonantoja, Helsinki (METLA). Related online version (cited on 7 May 2007): http://www.metla.fi/metinfo/monikaytto/lvvi/. 2.3, 1, 2.5

Sievänen, T., Pouta, E., Neuvonen, M. (2004), "Participation in mushroom picking in Finland", in Social Roles of Forests for Urban Population, (Eds.) Ito, T., Nobuhiko, T., Tokyo (Japan Society of Forestry Planning Press; University of Tokyo). 2.5, 4.1

Silvennoinen, H., Tyrväinen, L. (2001), "Luontomatkailun kysyntä Suomessa ja asiakkaiden ympäristätoiveet (Demand for nature tourism services and the environment in Finland)", in Luonnon virkistyskäyttö 2000 (Outdoor recreation 2000), (Ed.) Sievänen, T., vol. 802 of Metsäntutkimuslaitoksen tiedonantoja, pp. 112-127, Helsinki (METLA). 1, 2.7 
Simpson, M.C., Ladle, R. (2007), "Implementing sustainable tourism indicators for destinations using a quantifiable Tourism Sustainability Index", Journal of Sustainable Tourism, submitted. 4.4

Simpson, M.C., Ladle, R., Viner, D., Nicholls, S. (2007), "The vulnerability and resilience of Caribbean Small Islands States to climate change: A case study from Tobago Tourism Review International February 2007", unknown status. In press. 2.2, 3, 2.2

Skov-Petersen, H., Jensen, F.S. (2005), "Monitoring the recreational use of the nature - an international assessment", Larnaka, Cyprus, April 21-22, 2005, conference paper. Survey for COST Action E33, Working Group 2. 2.4

Spencer, D. (1997), "Counterurbanisation and rural depopulation revisited: Landowners, planners and rural development", Journal of Rural Studies, 13(1): 75-92, doi:10.1016/S07430167(96)00059-9. 2.2

Statistics Netherlands (1997), "Dagrecreatie 1995/'96 (Day trips 1995/'96)", Voorburg (Statistics Netherlands). 2.3, 1

Stueve, A.M., Cock, S.D., Drew, D. (2002), "The Geotourism Study: Phase 1 Executive Summary", Washington, DC (Travel Industry Association of America). Related online version (cited on 6 November 2006):

http://www.tia.org/pubs/geotourismphasefinal.pdf. 2.6

Thompson, C.W., Aspinall, P., Bell, S., Findlay, C. (2004), "Local open space and social inclusion: Case studies of use and abuse of woodlands in Central Scotland", Edinburgh (Forestry Commission). 3

The International Ecotourism Society (1991), "About Ecotourism: Definitions \& Principles", online resource. URL (cited on 6 November 2006):

http://www.ecotourism.org/webmodules/webarticlesnet/templates/?a=95\&z=2. 1, 2.6

Tyrväinen, L. (2001), "Use and valuation of urban forest amenities in Finland", Journal of Environmental Management, 62(1): 75-92. 3

Tyrväinen, L. (2006), "Nature tourism in Finland: Development Possibilities and Constraints", conference paper. Related online version (cited on 6 November 2006):

http://www.openspace.eca.ac.uk/coste33/outputs_northerneurope.htm. 2.7

Tyrväinen, L., Nousiainen, I., Silvennoinen, H., Tahvanainen, L. (2001), "Rural Tourism in Finland: Tourists' Expectation of Landscape and Environment", Scandinavian Journal of Hospitality and Tourism Research, 1(2): 133-149, doi:10.1080/150222501317244047. 3

Tyrväinen, L., Silvennoinen, H., Nousiainen, I. (2002), "Combining forestry and nature-based tourism in Finland: An analysis of development potentials and constraints", in Collaboration and Partnerships in Forestry, Proceedings of IUFRO Division 6 Meeting, 11-17 November, 2002, Valdivia, Chile, Vienna (IUFRO). CD-ROM. 2.7

Tyrväinen, L., Silvennoinen, H., Kolehmainen, O. (2003), "Ecological and Aesthetic Values be Combined in Urban Forest Management", Urban Forestry \& Urban Greening, 1(3): 135-149, doi:10.1078/1618-8667-00014. 3, 3

Tyrväinen, L., Pauleit, S., Seeland, K., de Vries, S. (2005), "Benefits and Uses of Urban Forests and Trees", in Urban Forests and Trees: A Reference Book, (Eds.) Konijnendijk, C.C., Nilsson, K., Randrup, T.B., Schipperijn, J., pp. 81-114, Berlin et al. (Springer). 3

Living Reviews in Landscape Research

http: //www . livingreviews . org/lrlr-2007-2 
Tyrväinen, L., Korpela, K., Silvennoinen, H., Ylen, M. (2006), "The importance of nature to Finns and the effect of the use of green areas on perceived health and restorative experiences", in Urban Forestry for Human Health and Wellbeing (Abstract book), (Eds.) Nilsson, K., Nielsen, A.B., COST E39 Research Conference / ASEM 2nd Symposium on Urban Forestry, Copenhagen, 28-30 June 2006, Copenhagen (Royal Veterinary and Agricultural University). Related online version (cited on 7 May 2007):

http://en.sl.life.ku.dk/KurserOgEfteruddannelse/ASEM-COST2006/

ConferenceProceedings. aspx. 3

Ulrich, R.S., Simons, R.F., Losito, B.D., Fiorito, E., Miles, M.A., Zelson, M. (1991), "Stress recovery during exposure to natural and urban environments", Journal of Environmental Psychology, 11: 201-230, doi:10.1016/S0272-4944(05)80184-7. 3

UNEP (2000), "UNEP Principles on the Implementation of Sustainable Tourism", online resource. URL (cited on 5 November 2006):

http://www. unepie.org/pc/tourism/policy/principles.htm. 4.3

USDA Forest Service (2006), "Research and Development information at the USDA Forest Service", project homepage. URL (cited on 26 November 2006):

http://www.fs.fed.us/research/social_science_research.shtml. 4.2

Vaage, O.F. (2004), Rapporter, 2004/13, Oslo (Statistics Norway). Related online version (cited on 7 May 2007):

http://www.ssb.no/emner/07/02/50/rapp_200413/. In Norwegian. 2.3, 1

Vemuri, A.W., Costanza, R. (2006), "The role of human, social, built, and natural capital in explaining life satisfaction at the country level: Toward a National Well-Being Index (NWI)", Ecological Economics, 58: 119-133, doi:10.1016/j.ecolecon.2005.02.008. 2.1

Vistad, O.I. (2003), "Experience and management of recreational impact on the ground - a study among visitors and managers", Journal for Nature Conservation, 11: 363-369, doi:10.1078/16171381-00069. 4.1

Walther, G.-R., Post, E., Convey, R., Menzel, A., Parmesan, C., Beebee, T.J.C., Fromentin, J.M., Hoegh-Guldberg, O., Bairlein, F. (2002), "Ecological responses to recent climate change", Nature, 416: 389-395, doi:10.1038/416389a. 2.2

Wells, M.P. (1997), Environment Department Papers: Environmental Economics Series, 55, Washington, DC (World Bank). Related online version (cited on 7 November 2006):

http://www.icrtourism.org/weblibrary. asp. 4.3, 5.3

World Tourism Organization (2001), "Global Code of Ethics for Tourism (GCET)", online resource. URL (cited on 9 May 2007):

http://www. world-tourism.org/code_ethics/eng.html. 4.3

World Tourism Organization (2004), "Indicators of Sustainable Development for Tourism Destinations: A Guidebook", Madrid (World Tourism Organization). 4.4

World Tourism Organization (2006), "Tourism Highlights: 2006 Edition", Madrid (World Tourism Organization). Related online version (cited on 7 November 2006):

http://www . world-tourism.org/facts/eng/pdf/highlights/highlights_06_eng_lr.pdf. 2.1

WTTC (1998), "WTTC Environmental Guidelines", London (WTTC). 4.3 
WWF (2001), "Guidelines for community-based ecotourism development", Gland (WWF International). Related online version (cited on 9 May 2007):

http://assets.panda.org/downloads/guidelinesen.pdf. 4.3 